\title{
1400 years of summer hydroclimate from stable isotopes in Iberian trees
}

3 Laia Andreu-Hayles ${ }^{1,2}$, Caroline C. Ummenhofer ${ }^{3}$, , Mariano Barriendos ${ }^{4,2}$, Gerhard H.

4 Schleser 5,6, Gerhard Helle ${ }^{5}$, Markus Leuenberger7, Emilia Gutiérrez ${ }^{8}$ and Edward R. Cook ${ }^{1}$

6 1. Tree-Ring Laboratory, Lamont-Doherty Earth Observatory of Columbia University,

7 Palisades, NY, USA.

8 2. Institut Català de Ciències del Clima (IC3), Barcelona, Catalonia, Spain.

9 3. Department of Physical Oceanography, Woods Hole Oceanographic Institution,

10 Woods Hole, MA, USA.

11 4. Department of Modern History, University of Barcelona, Spain.

12 5. Climate Dynamics and Landscape Evolution, German Centre for Geosciences,

13 Potsdam, Germany.

14 6. Research Center Juelich, Institute of Bio-and Geosciences, Agrosphere (IBG-3);

15 Juelich, Germany.

167 Climate and Environmental Physics, University of Bern, Switzerland.

17 8. Department of Ecology, University of Barcelona, Spain.

$19{ }^{*}$ Corresponding authors: Laia Andreu-Hayles <lah@ldeo.columbia.edu>, Tree-Ring

20 Laboratory, Lamont-Doherty Earth Observatory of Columbia University, 61 Route 9W,

21 Palisades, NY 10964, USA; Caroline C. Ummenhofer <cummenhofer@whoi.edu>,

22 Department of Physical Oceanography, Woods Hole Oceanographic Institution, Woods

23 Hole, MA, USA; 


\section{Abstract}

25 Tree rings are natural archives that annually record distinct types of past climate variability

26 depending on the parameters measured. Here, we use ring-width and stable isotopes in cellulose

27 of trees from the northwestern Iberian Peninsula (IP) to understand regional summer

28 hydroclimate over the last 400 years and the associated atmospheric patterns. Spatial correlations

29 between tree rings and gridded climate products demonstrate that isotope signatures in the

30 targeted Iberian pine forests are very sensitive to water availability during the summer period,

31 and are mainly controlled by stomatal conductance. Non-linear methods based on extreme events

32 analysis allow for capturing distinct seasonal climatic variability recorded by tree-ring

33 parameters and asymmetric signals of the associated atmospheric features. Moreover, years with

34 extreme high (low) values in the tree-ring records were characterised by coherent large-scale

35 atmospheric circulation patterns with reduced (enhanced) moisture transport onto the

36 northwestern IP. These analyses of extremes revealed that high/low proxy values do not

37 necessarily correspond to mirror images in the atmospheric anomaly patterns, suggesting

38 different drivers of these patterns and the corresponding signature recorded in the proxies.

39 Regional hydroclimate features across the broader IP and western Europe during extreme

40 wet/dry summers detected by the northwestern IP trees compare favourably to an independent

41 multicentury sea level pressure and drought reconstruction for Europe. These independent

42 sources of past climate validate our findings that attribute non-linear moisture signals recorded

43 by extreme tree-ring values to distinct large-scale atmospheric patterns and allow for 400 -yr

44 reconstructions of the frequency of occurrence of extreme conditions in summer hydroclimate. 
46 Keywords: tree rings, extreme analyses, atmospheric circulation, hydroclimate, Sea Level

47 Pressure (SLP), Old World Drought Atlas (OWDA), Iberian Peninsula

48 


\section{Introduction}

50 Located at the westernmost edge of the Mediterranean, the Iberian Peninsula (IP) is exposed to

51 atmospheric phenomena of Mediterranean and North Atlantic origin. Iberian hydroclimate is

52 characterised by strong spatiotemporal variability (Fig. 1). While some eastern and southern

53 Iberian regions are semi-arid, precipitation along the northern coast exceeds $1500 \mathrm{~mm} / \mathrm{yr}$ with

54 dry summers and wet cool seasons. Despite this, drought is a familiar occurrence in the IP:

55 analysing drought evolution during 1910-2000, Vicente-Serrano (2006) found intense and

56 widespread drought episodes in the 1940s, 1950s, 1980s, and 1990s, with higher intensity in

57 the central and western IP than in the northeastern region. Developing technical solutions to

58 recurring and extended water scarcity through infrastructure building, advanced water

59 management, and legislation has a rich and successful history over past centuries in Spain,

60 which is still reflected today in more dams per capita than in any other country in the world

61 (Llamas 2003). This is even more crucial considering the projected subtropical drying in a

62 warming world due to increased subsidence across the region driven by an expansion of the

63 Hadley cell (Lu et al. 2007; Previdi and Liepert 2007; Lu et al. 2009; Cai et al. 2012;

64 Karnauskas and Ummenhofer 2014; Lau and Kim 2015), which is likely to put further strain

65 on limited water resources in the future. The Mediterranean region has been identified as one

66 of the top climate change hot-spots worldwide (Giorgi 2006). Recent changes in IP

67 precipitation and temperature suggest that some of these trends towards increasing aridity are

68 already under way (Giorgi and Lionello 2008; De Luis et al. 2009; Hoerling et al. 2012).

69 More frequent extremes in hydroclimate, such as floods and droughts, are likely in a warming

70 world (Wentz et al. 2007; Trenberth 2011; Hartmann et al. 2013). Records of past hydroclimate

71 variability thus provide an important long-term context for devising management strategies for 
72 water resources. Tree rings are natural archives that can provide information about the Earth's

73 past environmental conditions with precise annual resolution. By applying dendrochronological

74 techniques, it is possible to assess the relationships between trees and environmental factors and

75 use this information to estimate climatic conditions before the existence of instrumental records:

76 i.e., generate palaeoclimatic reconstructions. The traditional tree-ring parameters are annual ring-

77 width (TRW) and maximum density (Fritts 1976), but annually resolved isotopic chronologies

78 based on tree-rings have increased in number during the last few decades (e.g., McCarroll and

79 Loader 2004; Seftigen et al. 2011; Gagen et al. 2012; Loader et al. 2013; Konter et al. 2014;

80 Labuhn et al. 2014; Naulier et al. 2015; and references therein). European multi-proxy

81 precipitation reconstructions over the last 500 years show distinct spatial, seasonal and temporal

82 patterns, especially between central Europe and the IP, including unstable relationships between

83 regional precipitation and large-scale atmospheric patterns (Cook et al. 2002; Pauling et al. 2006;

84 Vicente-Serrano and López-Moreno 2008). Although drought reconstructions covering Europe

85 (Cook et al. 2015) and specifically focused on the Mediterranean (Nicault et al. 2008) are also

86 available, the quality of the reconstructions is not spatially homogenous across the studied region,

87 in some case having issues over the IP. At a smaller scale, there are several temperature and

88 precipitation reconstructions in Spain based on TRW (Fernández et al. 1996; Manrique and

89 Fernandez-Cancio 2000; Dorado Liñán et al. 2015; Esper et al. 2015; Tejedor et al. 2015) or tree-

90 ring density chronologies (Buntgen et al. 2008; Dorado Liñán et al. 2012). Some studies used the

91 stable isotopic signatures of IP tree-rings for climate related studies (Andreu Hayles 2007;

92 Andreu et al. 2008; Planells et al. 2009; Andreu-Hayles et al. 2011; Dorado Liñan et al. 2012;

93 Konter et al. 2014; Dorado Liñán et al. 2015). 
94 Climate variability in the northwestern IP is associated with the North Atlantic Oscillation (NAO)

95 (Rodó et al. 1997; Rodriguez-Puebla et al. 1998). The NAO, defined by the pressure difference

96 between the Azores High and the Icelandic Low, determines the strength and position of the

97 westerly flow and thus, the main precipitation patterns across Europe, and to a lesser extent in

98 eastern North America, and Africa (Hurrell 1995). It also impacts fish inventories, agriculture,

99 and hydroelectric production through available water resources (Trigo et al. 2004; López-

100 Moreno et al. 2007; Vicente-Serrano and López-Moreno 2008). Although the NAO is considered

101 the dominant mode of interannual variability for European climate, its effect is dominant in

102 winter, as the associated pressure changes during summer are weaker and thus exert less

103 influence on hydroclimate variability (Trigo et al. 2008; Hernández et al. 2015). During summer,

104 storm track activity is reduced and European hydroclimate and in particular heat extremes are

105 often associated with atmospheric blocking situations (Lehmann and Coumou 2015). Links to

106 the Summer North Atlantic Oscillation (SNAO) have been made (Linderholm et al. 2009; Buwen

107 et al. 2013). During a positive SNAO, based on an index of July-August sea level pressure (SLP)

108 variability in the North Atlantic sector, anticyclonic conditions occur over the UK, whereas the

109 Mediterranean area is wet and cloudier (Bladé et al. 2011).

110 Here, we use tree-ring samples from a Pinus sylvestris relict forest (García Antón et al. 1997)

111 located at 1600 m.a.s.l in the Cantabrian range near to the village 'La Puebla de Lillo' (herein

112 Lillo) to infer hydroclimate variability for the last 400 years in northwestern Iberia (Fig. 1).

113 Using three different tree-ring parameters from the same chronology: TRW, carbon $\left(\delta^{13} \mathrm{C}\right)$ and

114 oxygen $\left(\delta^{18} \mathrm{O}\right)$ stable isotopes, we applied linear and non-linear methods to determine the

115 climatic signal recorded by these trees. Our findings include significant linkages between distinct 
116 tree-ring proxies and regional late spring and summer precipitation associated with specific

117 atmospheric patterns.

\section{Data and methods}

\section{$120 \quad 2.1$ The tree-ring chronologies}

121 The TRW, $\delta^{13} \mathrm{C}$ and $\delta^{18} \mathrm{O}$ data presented here have been previously used in studies with

122 different goals (e.g., Treydte et al. 2007; Andreu et al. 2008; Andreu-Hayles et al. 2011;

123 Saurer et al. 2014; Frank et al. 2015). The TRW series were standardised using the residual

124 method with a 250-yr spline (Cook and Kairiukstis 1990) on power transformation (Cook and

125 Peters 1997). Other standardisation, such as the Signal Free method (Melvin and Briffa 2008)

126 or the Friedman super smooth (Friedman 1984), were explored without leading to large

127 differences among the resulting chronologies. In relation to the isotopic analyses, wood from

128 four trees was pooled year by year (Leavitt and Long 1984; Dorado Liñán et al. 2011). The $\alpha-$

129 cellulose was extracted using sodium hydroxide, sodium chlorite and acetic acid. (Loader et al.

130 1997) and was homogenised using an ultrasonic device (Laumer et al. 2009). Stable isotopes

131 ratios are expressed in the delta $(\delta)$ notation in per mil (\%o) relative to the standards of the

132 Vienna Pee Dee Belemnite (VPDB) for $\delta^{13} \mathrm{C}$ and the Vienna Standard Mean Ocean Water (V-

133 SMOW) for $\delta^{18} \mathrm{O} \cdot \delta^{13} \mathrm{C}$ ratios were measured by combusting the cellulose in an elemental

134 analyser (Fisons NA $1500 \mathrm{NC}$, Fisons Instruments, Milan, Italy) interfaced with an IRMS

135 (Micromass Optima isotope ratio mass-spectrometer, VG Instruments, Manchester, UK)

136 operating in continuous flow mode. Cellulose from spruce ("Fluka1", Fluka Chemika, Ord.\#

137 22181, Lot. \# 380099/1 20200; $\delta^{13} \mathrm{C}_{\mathrm{VPDB}}=-23.03 \%$ ) and graphite powder (“G5”, 20-40 $\mu \mathrm{m}$,

138 purity 99.99\%; $\delta^{13} \mathrm{C}_{\mathrm{VPDB}}=-21.16 \%$ ) were used as laboratory standards for $\delta^{13} \mathrm{C}$ after 
139 calibration against IAEA CH-3 (-24.7\%), IAEA-CH7 (-32.15\%) and USGS24 (-16.04\%).

140 The $\delta^{18} \mathrm{O}$ values were measured using high-temperature pyrolysis $\left(1350^{\circ} \mathrm{C}\right)$ of cellulose to

141 carbon monoxide in a Thermo Chemical Elemental Analyser (TC/EA) coupled via a ConFlow

142 II open split to the IRMS (Thermo Finnigan Delta Plus XL IRMS). The measurements'

143 reproducibility was better than $0.1 \%$ and $0.3 \%$ for $\delta^{13} \mathrm{C}$ and $\delta^{18} \mathrm{O}$ ratios, respectively. The

144 laboratory standards used for $\delta^{18} \mathrm{O}$ were IAEA-C3 cellulose (32.6 $\left.\pm 0.2 \%\right)$, IAEA-CH6 sucrose

$145(36.4 \pm 0.2 \%$ ) and Merk cellulose $(28.67 \pm 0.2 \%$ ) after calibration against V-PDB and

146 converted then to V-SMOW by using $\delta_{\mathrm{VSMOW}}=1.0415 \delta_{\mathrm{PDB}}+41.5 \%$ IAEA standards (Borella

147 et al. 1999). In order to remove non-climatic trends from the raw $\delta^{13} \mathrm{C}$ tree-ring data: we

148 applied (1) the atmospheric correction to avoid disturbances due to the Suess effect (increase

149 in ${ }^{13} \mathrm{C}$-depleted atmospheric $\mathrm{CO}_{2}$ due to fossil-fuel burning and deforestation since the

150 industrialisation) using the values listed by McCarroll and Loader (2004); (2) the pin

151 correction (McCarroll et al. 2009) to account for the tree ecophysiological response due to

152 higher $\mathrm{CO}_{2}$. There are constant fractionation processes affecting the $\delta^{13} \mathrm{C}$ signatures due to

$153 \mathrm{CO}_{2}$ diffusion through stomata and carboxylation (by Rubisco during photosynthesis), but

154 other fractionations can also occur due to changes in the environmental conditions. These are

155 the signals sought in this paper.

\subsection{Observational/reanalysis and gridded reconstruction products}

158 A series of monthly global gridded observational and reanalysis products were used to assess

159 regional hydroclimate and the associated large-scale atmospheric conditions that give rise to

160 extremes in the tree-ring proxies. The primary variables that we compare directly with the tree

161 ring proxies are temperature and precipitation at the Lillo study site (box in Fig. 1) that 
162 directly affect tree growth and physiological processes. However, an important goal of the

163 paper was to assess the large-scale circulation features that give rise to these two variables

164 representing hydroclimate. It is not implied that trees directly record or are sensitive to SLP

165 anomalies; rather the study aims to advance understanding of tree ring proxy reconstructions

166 by gaining indirect information about large-atmospheric patterns in the past by knowing how

167 the trees respond to hydroclimatic variations.

168 At $2.5^{\circ}$ horizontal resolution, these include zonal and meridional winds, and specific humidity

169 from the National Centers for Environmental Prediction (NCEP)/National Center for

170 Atmospheric Research (NCAR) reanalysis (NNR; 1948-present; Kalnay et al. 1996; Kistler et

171 al. 2001) and the $2^{\circ}$ horizontal resolution 20th Century reanalysis (20CR; 1871-2011; Compo

172 et al. 2011); precipitation at $0.5^{\circ}$ horizontal resolution from the Global Precipitation

173 Climatology Centre (GPCC; version 6; 1901-2010; Schneider et al. 2014) and temperature at

$1740.5^{\circ}$ resolution from the Climate Research Unit (CRU TS 2.1; 1901-2002; Mitchell and Jones

175 2005). The common analysis period was taken as 1925-2002 (see section below), though

176 results were repeated for the more recent period post-1957 with improved data coverage.

177 Given the robustness of the results, we only show analyses for the longer period 1925-2002.

178 Prior to the instrumental period, we used two $0.5^{\circ}$ resolution gridded products: reconstructions

179 of SLP fields from 1500-1999 (Luterbacher et al. 2002) and the Old World Drought Atlas

180 (OWDA), a set of yearly maps of the reconstructed self-calibrating Palmer Drought Severity

181 Index (scPDSI) for the summer season during the Common Era based on tree rings (Cook et al.

182 2015).

183

\section{$184 \quad 2.3$ Analysis approach}


185 The calibration period overlapping between the proxies and instrumental data was from 1925 to

186 2002, after excluding the beginning of the 20th century due to continuous extreme low values

187 observed in the TRW chronology. The persistence and magnitude of this disturbance pattern over

188 more than two decade suggest a non-climatic origin. Most of the sampled trees had scars

189 produced by the extraction of torches, an activity that is documented to have occurred in the

190 studied forest from the end of the $19^{\text {th }}$ century to the $1^{\text {st }}$ quarter of the 20th century (Orden

191 Martín 2013). The same analyses performed over the entire possible calibration period (1901-

192 2002) show consistent results with the ones presented here, although some lower climatic

193 sensitivity in some of the proxies was observed (results not shown). The time span used for the

194 pre-instrumental or historical period from 1665 to 1900 was determined by the reliable time-span

195 of the TRW chronology starting in 1663 that was assessed by an Expressed Population Signal

196 statistic higher than 0.85 (Wigley et al. 1984).

197 Time-series of climate data for the Lillo region were created as area-average for the domain

198 delimited by the red box ( 42.25 to $43.75 \mathrm{~N} ; 2.75$ to $7.75 \mathrm{~W})$ shown in Fig. 1, based on the

199 GPCC precipitation (Schneider et al. 2014) and the CRU temperature (Mitchell and Jones

200 2005) gridded data sets. The initial identification of monthly and seasonal climate signals in

201 the tree-ring data was assessed through correlations (Fig. 2) of the three tree-ring chronologies

202 (Fig. 3) with precipitation, as well as partial correlations with mean temperature data

203 controlling the influence of precipitation using the approach implemented in Seascorr (Meko

204 et al. 2011).

205 An analysis of extremes was used to (1) provide insights on the physiological processes

206 affecting the tree-ring proxies (box plot analyses, Fig. 4); (2) to accommodate non-linear tree-

207 ring responses to variations in hydroclimate with regard to the sign of the anomaly and its 
208 seasonality (seasonal cycles; Fig. 5); (3) to understand the seasonal large-scale atmospheric

209 mechanisms associated with these years (composite maps; Fig. 6 and 7). As is customary for

210 non-normally distributed variables, such as precipitation, all values in the three tree-ring proxy

211 time-series were ranked and the lowest/highest decile (i.e. extremes) were selected. This led to

212 a selection of 8 high and 8 low extreme years for the instrumental period 1925-2002 (Table 1)

213 and a total of 23 high and 23 low extreme years for the historical period 1665-1900 (Table 2)

214 comprising 236 years. All extreme years are shown in Fig. 3 (filled circles) and the associated

215 other proxy values for the extreme years are compared using box-and-whisker plots in Fig. 4.

216 We assessed the characteristics of the seasonal cycle of Lillo precipitation and surface air

217 temperature (SAT) during these 8 years with extreme high/low proxy values for the

218 instrumental period, with the coloured lines indicating the mean seasonal cycle for the three

219 parameters (Fig. 5d-i). To determine whether the mean seasonal cycle during these extreme

220 years differs significantly from average years a boot-strapping method (i.e., Monte Carlo test)

221 was employed: for a particular time-series, 8 random years were selected for the period 1925-

222 2002. This was repeated 25,000 times to generate an expected distribution of the seasonal

223 cycle for any given set of 8 years. The grey shading in Fig. 5d-i represents the $90 \%$

224 significance level of this expected distribution for high/low years. Wherever a coloured line

225 lies outside the grey shading, the precipitation or SAT in the extreme years differs

226 significantly from average conditions.

227 Using those same years, composite anomalies (Fig. 6-7) of precipitation, SAT, moisture

228 transport, and SLP were calculated for those months when the seasonal precipitation cycle

229 during extreme years deviates significantly from average rainfall conditions based on all years.

230 A two-tailed $t$-test was used to determine whether composite anomalies of precipitation, SAT, 
231 moisture transport, and SLP were significant at the 90\% level from the long-term mean based

232 on all years.

233 The years with extreme values in the palaeo proxy time-series (TRW, $\delta^{13} \mathrm{C}$, and $\delta^{18} \mathrm{O}$ ) for the

234 previous centuries were detected by 2 distinct approaches: (a) decile method: 23 high/low

235 extreme proxy years detected as deciles for the period 1665 to 1900 (Fig. 3, filled circles); (b)

236 threshold method: years with proxy values that exceeded a threshold value determined by the

237 lowest of the uppermost decile and the highest of the lowermost decile of the proxy values in the

238 analysis period 1925-2002 (Table 1; horizontal red/blue line in Fig. 3a-c and Fig. 5a-c; empty

239 circles and crosses in Fig. 3). For those high/low extreme proxy years detected by the threshold

240 method throughout the historical period (1665-1900), composite anomalies were calculated for

241 SLP reconstructed fields over the eastern North Atlantic region and Europe (Luterbacher et al.

242 2002) in Fig. 8 and for PDSI based on the Old World Drought Atlas (OWDA; Cook et al. 2015)

243 in Fig. 9. Composites were also calculated for the 8 high/low extreme years for the instrumental

244 period for validating the method for SLP (Fig. 10) and PDSI (Fig. 11). Fig. 12 shows variations

245 in the number of occurrence of years with extreme events per decade obtained in 20-yr sliding

246 windows for the two isotope proxies. The temporal evolution of extreme events is only shown

247 for the sign, for which strong significant deviations in the seasonal cycle of Lillo precipitation

248 were detected (cf. Fig. 5d-f).

2503 Distinct climatic signals in the tree ring proxies

251 The climatic signal recorded by each tree-ring proxy (TRW, $\delta^{13} \mathrm{C}$ and $\delta^{18} \mathrm{O}$ ) show distinct

252 strength and seasonality (Fig. 2). Tree growth, represented by TRW records, is mildly favoured

253 by wet conditions from April to August (i.e. positive correlation between TRW and 
254 precipitation); in contrast the effect of temperature, with the precipitation effect removed, seems

255 to be negligible without a single month with significant correlation. The tree-ring parameter most

256 sensitive to summertime water availability is $\delta^{13} \mathrm{C}$. The $\delta^{13} \mathrm{C}$ records exhibit the highest climate

257 sensitivity with significant negative correlation with June-July precipitation and positive partial

258 correlation with July-August temperatures. The $\delta^{18} \mathrm{O}$ records exhibit weaker correlations, but

259 similar seasonal sensitivity to $\delta^{13} \mathrm{C}$ with negative and positive correlations from May to July

260 precipitation and July to September temperatures, respectively (Fig. 2). Therefore, both stable

261 isotopic ratios $\left(\delta^{13} \mathrm{C}\right.$ and $\left.\delta^{18} \mathrm{O}\right)$ seem to be mainly modulated by changes in moisture during

262 summer time.

\section{Physiological processes related to climate variability}

265 The $\delta^{13} \mathrm{C}$ ratios may be lower (ratios depleted in the heavier isotope ${ }^{13} \mathrm{C}$ ) during wet summers

266 because more open stomata lead to more $\mathrm{CO}_{2}$ available in the stomatal chambers. This leads to

267 more discrimination against the heavier isotope, ${ }^{13} \mathrm{C}$, since the lighter isotope, ${ }^{12} \mathrm{C}$, is preferred as

268 a substrate for photosynthesis (Farquhar et al. 1982). Dry summers may lead to higher $\delta^{13} \mathrm{C}$

269 values (ratios enriched in ${ }^{13} \mathrm{C}$ ) since closer stomata allow less $\mathrm{CO}_{2}$ availability in the stomatal

270 chambers, and thus discrimination against ${ }^{13} \mathrm{C}$ is lower.

271 An enrichment (depletion) of the $\delta^{13} \mathrm{C}$ isotopic signature due to higher (lower) assimilation rates

272 linked to temperature or light influences on photosynthesis (McCarroll and Pawellek 1998)

273 cannot be initially ruled out. Both physiological processes (i.e. assimilation increase and

274 reduction in stomata conductance) produce the same isotopic signature as a result of

275 reducing/increasing the ${ }^{12} \mathrm{C}$ availability in the stomatal chambers. However, our results show

276 significantly lower and higher $\delta^{13} \mathrm{C}$ ratios during the years with the 8 highest and 8 lowest 
277 growth observed (Fig. 4a), respectively. This suggests a stronger regulation by stomatal 278 variations (e.g. close stomata may lead to higher $\delta^{13} \mathrm{C}$ and lower TRW) compared to assimilation 279 (e.g. more photosynthesis may lead to higher $\delta^{13} \mathrm{C}$ and higher TRW).

280 The $\delta^{18} \mathrm{O}$ values are mainly affected by the original values of the $\delta^{18} \mathrm{O}$ of the source water and 281 the fractionation processes at the leaf level through stomatal conductance (Barbour 2007), 282 mechanism explained above for $\delta^{13} \mathrm{C}$. This leads to lower $\delta^{18} \mathrm{O}$ ratios (depleted in heavy isotopes, $283{ }^{18} \mathrm{O}$ ) during wet summers and to higher $\delta^{18} \mathrm{O}$ ratios (enriched in ${ }^{18} \mathrm{O}$ ) during dry summers. During 284 cyclonic wet summers, $\delta^{18} \mathrm{O}$ ratios in cellulose are lower because of low $\delta^{18} \mathrm{O}$ values in rainfall 285 (source water) and a lowered evaporative enrichment process at the leaf level due to lower 286 vapour pressure due to moist air (Young et al. 2015). In contrast during anticyclonic conditions, 287 the opposite fractionation processes occur.

288 Temperatures may also have an independent effect on precipitation supported by the significant 289 partial correlations with both stable isotopic series after removing the influence of precipitation 290 on the tree-ring proxies. Warm and cold summers may enhance the enrichment (high) and 291 depletion (low) of isotopic ratios, respectively, via changes in vapour pressure at leaf level 292 through stomata conductance. In summary, higher $\delta^{13} \mathrm{C}$ and $\delta^{18} \mathrm{O}$ values ( enriched) document 293 drier and warmer conditions, whereas lower $\delta^{13} \mathrm{C}$ and $\delta^{18} \mathrm{O}$ values ( depleted) are related to 294 wetter and colder conditions.

295 The years detected by the $\delta^{13} \mathrm{C}$ and $\delta^{18} \mathrm{O}$ extreme values do not always coincide with 6 out of 8 296 and 3 out of 8 matches for wet years and dry years, respectively (Table 1). Despite this, the box 297 plot analyses (Fig. 4) confirm the coherence between both proxies. During the 8 years with the 298 lowest / highest $\delta^{13} \mathrm{C}$ ratios (Fig. 4e), the $\delta^{18} \mathrm{O}$ values were significantly lower and higher, 299 respectively. Likewise during years with the 8 lowest / highest $\delta^{18} \mathrm{O}$ ratios (Fig. 4f), the $\delta^{13} \mathrm{C}$ 
300 ratios were significantly lower and higher, respectively. A correlation value of 0.58 between the

$301 \delta^{13} \mathrm{C}$ and $\delta^{18} \mathrm{O}$ records supports that summer moisture availability is regulating both isotopes at

302 the leaf level.

303 Nevertheless, other environmental factors are also independently modulating each proxy. The

304 lower climatic sensitivity of $\delta^{18} \mathrm{O}$ compared to $\delta^{13} \mathrm{C}$ records may be partially due to the

305 contribution of the original values of the source water (Saurer et al. 2002) and fractionation

306 processes occurring in this meteoric water until the fixation of the $\delta^{18} \mathrm{O}$ in plant tissue (McCarroll

307 and Loader 2004).

\section{Asymmetric moisture signal in high and low extreme proxy years}

309 Figure 5 shows the tree-ring series and seasonal cycle for precipitation and temperature for the

310 study site Lillo (red box in Fig. 1) for the instrumental period 1925-2002. Years recording the

311 highest/lowest $10 \%$ of the values in each tree-ring record (i.e. deciles) were selected (blue/red

312 filled circles in Fig. 5 for (a) TRW, (b) $\delta^{13} \mathrm{C}$, and (c) $\delta^{18} \mathrm{O}$ ), and used to calculate the seasonal

313 cycle in precipitation $(\mathrm{d}, \mathrm{f})$ and temperature $(\mathrm{g}, \mathrm{i})$. Blue lines illustrate the seasonal cycle for

314 years with high precipitation detected by wide (high) TRW, depleted (low) $\delta^{13} \mathrm{C}$ and depleted

315 (low) $\delta^{18} \mathrm{O}$ values. Red lines show the seasonal cycle for years with low precipitation detected

316 by narrow (low) TRW, enriched (high) $\delta^{13} \mathrm{C}$ and enriched (high) $\delta^{18} \mathrm{O}$. Therefore, significantly

317 wetter conditions than average (blue lines outside the grey band) are detected in June by

318 extreme wide TRW values and in June-July by extreme low $\delta^{13} \mathrm{C}$ and $\delta^{18} \mathrm{O}$ ratios. In contrast,

319 significantly drier conditions (red lines outside the grey band) are detected in June associated

320 with the narrowest TRW and the highest $\delta^{13} \mathrm{C}$, and in May related to extreme high $\delta^{18} \mathrm{O}$ ratios.

321 For the temperature seasonal cycles (g-i), blue lines indicate that these years exhibit low

322 temperatures in July-August detected by depleted (low) $\delta^{13} \mathrm{C}$ and in July by depleted (low) 
$323 \delta^{18} \mathrm{O}$. Red lines indicate warm conditions in July and August for years with enriched (high)

$324 \delta{ }^{13} \mathrm{C}$. Extreme wide TRW are significantly related to warm temperatures in April that may

325 favour the onset of the growing season, while narrow TRW seem to be associated, albeit not

326 significantly, with warmer temperatures during June and July.

327 These seasonal cycle analyses indicate that months with significant deviations from average

328 climatic conditions differ between years with extreme high and low proxy values. Thus, timing

329 (years and seasons) of climatic extremes is different for high and low extremes of the same proxy.

330 For instance, in years with extreme high $\delta^{13} \mathrm{C}$ values (Fig. 5b) significantly drier conditions

331 occurred during June (Fig. 5e), but the wetter conditions detected by the low $\delta^{13} \mathrm{C}$ value occurred

332 during July-August (Fig. 5e). Overall, climatic sensitivity is seasonally shifted between proxy

333 high/low values: dry conditions are detected to occur earlier in the year in late spring, while wet

334 conditions are found to occur later more focused on the summer months.

\section{Atmospheric patterns associated with dry/wet conditions}

337 The months identified by the precipitation seasonal cycle analysis with significant deviations

338 in precipitation from mean conditions are consistent with large-scale atmospheric features 339 described by composite analyses for the same months (Fig. 6-7). Our composite anomaly maps

340 indicate different circulations patterns for high and low extreme years. It should be noted that

341 the composites show anomalies rather than the mean field, so the circulation changes thus

342 relate more to a strengthening or weakening of the westerly onshore moisture transport for

343 example, rather than a complete change in direction and therefore change in source water 344 region. 


\subsection{Wet summer conditions}

347 The seasonal temperature and precipitation cycles in years with extreme low $\delta^{13} \mathrm{C}$ values (Fig. $5 b$ )

348 show significantly colder conditions for July (Fig. 5h) and wetter during June-July (Fig. 5e),

349 respectively. The June-July composites for years with extreme low $\delta^{13} \mathrm{C}$ show significantly

350 wetter and colder conditions for the Cantabrian range, western Iberia and southwestern France

351 (Fig. 6b,e). This is associated with an enhanced onshore moisture transport from the Atlantic

352 Ocean (Fig. 6h) driven by significant positive SLP anomalies at high latitudes and negative

353 anomalies over Europe (Fig. 6k). Similar patterns are found during years with low $\delta^{18} \mathrm{O}$ values

354 (Fig. 5c) with significant anomalies in the precipitation and temperature seasonal cycles detected,

355 corresponding to wetter (Fig. 5f) and colder (Fig. 5i) early summer conditions. Composite

356 anomalies for these years during June-July confirm significantly higher precipitation over the

357 northern IP and southern France (Fig. 6c), enhanced moisture transport from the Atlantic (Fig. 6i)

358 and consistent SLP patterns (Fig. 61), with significantly colder conditions across the IP (Fig. 6f).

359 The composites corresponding to years with wide TRW values associated with anomalous wet

360 conditions for June in the seasonal cycle (Fig. 5d) show higher precipitation along the northern

361 IP (Fig. 6a), associated with coherent moisture transport (Fig. 6g) and SLP patterns (Fig. 6j), as

362 well as colder temperatures over the IP (Fig. 6d). The moisture transport in years with high TRW

363 values shows more local atmospheric features with moisture coming directly from the west (Fig.

$3646 \mathrm{~g}$ ), resulting in local precipitation events at the study site (Fig. 6a). In contrast, moisture

365 transport patterns associated with the low isotopic values (Fig. 6h, i) exhibit more broad-scale

366 anomalous moisture transport features spanning across western Europe and western North Africa

367 that lead to anomalous precipitation over a larger region of the IP and into southern France (Fig. 
$3686 \mathrm{~b}, \mathrm{c})$. These large-scale patterns detected by extreme isotopic values are associated with

369 anomalous high SLP anomalies over Iceland and low SLP anomalies over Europe.

\section{$371 \quad 6.2$ Dry late spring-early summer conditions}

372 In years with extreme high $\delta^{13} \mathrm{C}$ values (Fig. 5b) significantly drier conditions occurred during

373 June (Fig. 5e) and warmer conditions during July-August (Fig. 5h). In agreement, composite

374 anomaly maps for June for high $\delta^{13} \mathrm{C}$ years indicate significant reductions in precipitation over

375 the northwestern IP (Fig. 7b) and positive temperature anomalies over the IP (Fig. 7e), associated

376 with coherent large-scale atmospheric circulation patterns. Anomalously low SLP over Iceland

377 and Greenland and high SLP anomalies over western and southern Europe (Fig. 7k) result in a

378 reduced moisture transport into the IP (Fig. 7h). In years with extreme high $\delta^{18} \mathrm{O}$ values

379 significantly drier conditions occur in May (Fig. 5f). Accordingly, the associated composite

380 maps for May reveal significant reductions in precipitation over the western IP (Fig. 7c) and

381 positive SAT anomalies across the wider IP and into France (Fig. 7f), associated with coherent

382 large-scale atmospheric circulation patterns. Anomalously low SLP over the North Atlantic and

383 high SLP over Europe (Fig. 71) result in a reduced moisture transport into the IP (Fig. 7i). While

384 moisture transport composites for high isotopic years (Fig. 7h, i) share again very similar

385 transport patterns, moisture advection detected by low TRW values (Fig. 7g) indicates a 386 particular circulation pattern associated with positive anomalies over Iceland (Fig. 7j), warmer 387 conditions over the central and southern IP (Fig. 7d) and drier conditions over the Pyrenees, but 388 not over Lillo where the trees are located (Fig. 7a). 
391 Seasonal composites computed for the period 1665 to 1900 using the SLP gridded product

392 (Luterbacher et al. 2002) and the Old World Drought Atlas (Cook et al. 2015) corroborated the

393 detection of wet/dry years in the pre-instrumental period. Table 2 shows the extreme years

394 detected using the two approaches (decile and threshold method). The composite analyses using

395 years from both approaches led to similar results. Thus, herein we just show results derived from

396 the threshold method.

397 The SLP composites computed using years with high TRW (Fig. 8a), low $\delta^{13} \mathrm{C}$ (Fig. 8b) and low

$398 \delta^{18} \mathrm{O}$ (Fig. 8c) represent SLP patterns that are consistent with wet conditions in the IP. In contrast,

399 low TRW (Fig. 8d), high $\delta^{13} \mathrm{C}$ (Fig. 8e) and high $\delta^{18}$ O (Fig. 8f) show SLP patterns mostly

400 associated with dry conditions over the IP. Overall, pre-instrumental SLP composites (Fig. 8)

401 compare well with SLP instrumental observations (Fig. 7, 8 and 10), mainly showing low and

402 high pressure anomalies over Europe during wet and dry events, respectively. More specifically,

403 the anomalies in the pre-instrumental period resemble the SLP patterns seen during extreme wet

404 summer months well (Fig. 8a-c and 10a-c), while there is less agreement for the dry extremes

405 (Fig. 8d-f and 10d-f). For the latter, the SLP anomalies over central and southern Europe are

406 consistent between the instrumental and pre-instrumental period, while it is the sign and location

407 of maximum SLP anomalies over northern Europe that differ. The OWDA composites (Fig. 8)

408 indicate mainly wet conditions (Fig. 8a-c) for years with high TRW and low isotopic ratios,

409 whereas non-significant or slightly dry conditions occur over the Lillo area (Fig. 8d-f) for years

410 with low TRW and high isotopic ratios. In addition, SLP (1925-1999; Fig. 10) and OWDA

411 (1925-2002; Fig. 11) composites for the instrumental period also show consistent results with the

412 expected dry and wet years depending on low/high extreme values detected in the tree ring

413 proxies. Therefore, these composites corroborate the validity of our approach of using extreme 
414 analyses in tree-ring records to explore the occurrence of wet and dry periods prior to the 415 instrumental period.

416 The three tree-ring parameters present distinct sensitivity to summer moisture availability, while

417 high and low extremes exhibit distinct seasonality and an asymmetric moisture signal. Whereas

418 TRW seems to reflect local atmospheric circulation features, stable isotopes share some large-

419 scale atmospheric patterns across the IP and western Europe that are of interest for this study in

420 order to infer changes in water availability over the IP more broadly. Here, we propose a novel

421 non-linear method to explore past hydroclimatic variability based on the analysis of extremes in

422 the isotopic series to detect specific years in the past (Table 2), in which the proxies recorded

423 significant deviations from average hydroclimatic conditions. Thus, the most likely occurrence

424 of years with wet/dry conditions is recorded independently by each tree-ring parameter for the

425 last 400 years, allowing for precise seasonality and attribution to related atmospheric patterns.

426 Specifically, the extreme isotopic values respond to summertime/late spring moisture availability:

427 wet June-July (low $\delta^{13} \mathrm{C}$ and low $\delta^{18} \mathrm{O}$ ), dry June (high $\delta^{13} \mathrm{C}$ ) and dry May (high $\delta^{18} \mathrm{O}$ ). Hence,

428 these isotopic records are used as proxies for informing about northwestern IP hydroclimate

429 variability during late spring/early summer during the period 1665 to 1900 (Fig. 12).

430 A consistent wet period in the second half of the 19th-century is the most prominent feature

431 for the reconstruction of wet summers (Fig. 12a) based on the high occurrence of wet years

432 detected by low values in the isotopic proxies (Table 2). This is reflected in low $\delta^{13} \mathrm{C}$ values

433 for an extended period of time and even more pronounced in low $\delta^{18} \mathrm{O}$ centred around 1850.

434 Undoubtedly, indicators of 'wetness' (depleted isotope values), agree on the persistent mid-

435 19th century pluvial. In addition, any 'dryness' indicators (enriched isotope values) are absent

436 during that period as shown in the reconstruction of dry late spring-early summer (Fig. 12b). 


\section{Discussion}

438 The persistent mid-19 ${ }^{\text {th }}$ century pluvial seen in our reconstruction (Fig. 12) is corroborated by

439 higher than usual precipitation levels reported between 1835 and 1875 in Barcelona (northeast

440 IP) based on a recently published high-quality instrumental record (Prohom et al. 2015), with a

441 6-year record of rainy years $(\sim 1840 s-1850 s)$, unique in the next 160 years (Rodrigo and

442 Barriendos 2008; Camuffo et al. 2013). Moreover, historical documentation also reported a

443 lack of droughts and more frequent and severe catastrophic floods in the mid-19 $9^{\text {th }}$ century in

444 Iberia (Barriendos and Martin-Vide 1998; Llasat et al. 2005; Barriendos and Rodrigo 2006),

445 ending this period of extreme floods with the 1874 Santa Tecla flash flood in Catalonia with

446 more than 500 deaths (Ruiz-Bellet et al. 2015). This 19th century pluvial period is also

447 confirmed by higher frequency of extreme events, such as strong snowstorms, marine storms,

448 atmospheric convective activity and catastrophic floods, reported without a well-marked

449 seasonality (Barriendos and Martin-Vide 1998). This unusual occurrence of wet years,

450 associated with high atmospheric instability, may result from a prevalent meridional

451 circulation associated with cold air aloft, which - upon contact with warm/humid air masses

452 from the Mediterranean - may trigger torrential rainfall over the IP, especially over the

453 northeastern IP (Barriendos and Martin-Vide 1998). These severe atmospheric events may

454 also be associated with marked negative NAO phases and advection of cooler air aloft, 455 producing strong rainfall events during such a 'cold phase' across the entire northern IP, and

456 thus being detectable on both sides: northeastern (i.e. Mediterranean) and northwestern (i.e.

457 Atlantic) IP, where our study site is located.

458 This information based on historic data aligns with the synoptic situation reported in our 459 composite maps from the instrumental and pre-instrumental periods. During the instrumental 
460 period, low $\delta^{13} \mathrm{C}$ and $\delta^{18} \mathrm{O}$ years show circulation anomalies that are consistent with this

461 interpretation with anomalous high SLP over Iceland and lower in the mid-latitudes (Fig. 6k,1),

462 leading to anomalous northwesterly moisture transport from the Atlantic onto the IP (Fig. 6h,i).

463 These circulation features are also associated with anomalous cool SAT across the broader IP

464 (Fig. 6e,f). In the pre-instrumental period, the SLP anomaly pattern associated with low $\delta^{18} \mathrm{O}$

465 years during this unusual pluvial period (Fig. 8c) is indicative of the negative NAO conditions 466 suggested above.

467 Nevertheless, not all the atmospheric events occurred synchronically between the Atlantic and

468 the Mediterranean sides of the northern IP. During the late Maunder Minimum (1675-1715)

469 historic data based on Catholic rogation ceremonies from northeastern locations in Catalonia

470 show almost no drought with steady precipitation levels (Barriendos 1997), whereas rogations

471 from locations with a stronger Atlantic influence show drier conditions, such as Toledo and

472 Zamora located in the western IP during spring (Domínguez-Castro et al. 2010) and the Ebro

473 basin (Vicente-Serrano and Cuadrat 2007). This situation may be linked to a prevalent

474 anticyclone associated with cold conditions that may lead to dry weather in the Atlantic region,

475 but to moderate precipitation levels in the Mediterranean side driven by moisture coming from

476 the East. Consistently with the historical findings from the Atlantic side, our late spring-early

477 summer reconstruction (Fig. 12b) indicates higher occurrence of dry years detected by high

478 values in both isotopic records during the late Maunder Minimum.

479 In contrast, other dry periods were co-occurring across the entire northern IP, as for example a 480 drought during 1775-1778, evident in the Ebro basin under a strong Atlantic influence 481 (Vicente-Serrano and Cuadrat 2007). The anomalous climatic conditions extended along the

482 Mediterranean coast and is considered one of the strongest climatic irregularities occurring 
483 during the Maldà Oscillation in Catalonia, northeastern IP (Barriendos and Llasat 2003). This

484 period was likely associated with sustained high pressure anomalies over central Europe

485 (Luterbacher et al. 2000), which may have produced a 'blocking' situation preventing the

486 arrival of low pressure systems from the Atlantic Ocean. In our high $\delta^{13} \mathrm{C}$ years indicative of

487 dry June conditions, the SLP anomalies (Fig. 7h, Fig. 8e) show comparable features to such a

488 scenario, which could have led to prolonged droughts in the Western Mediterranean Basin,

489 interspersed with flooding events (Barriendos and Llasat 2003).

490 Overall, our isotopic tree-ring reconstruction shows the most noticeable period with frequent

491 dry summers from 1665 to 1700 considering the total extent spanning until 1900. In agreement,

492 historical data from Toledo Cathedral based on rogations reported the most severe droughts

493 occurring between 1576-1800, whereas almost no droughts were found during the 1800-1900

494 period (Dominguez-Castro et al. 2008). That this period displays a lack of droughts agrees

495 with the $19^{\text {th }}$ century pluvial situation described in Fig. 12a. In addition, years with extreme

496 values in the tree-ring proxies (Table 2) concur with some particular years of extreme droughts

497 described by historical documentation, such as the years 1680 (Domínguez-Castro et al. 2010),

4981753 , 1817 or 1824 (Domínguez-Castro et al. 2012). Finally, the drought period detected by

499 the isotopic tree-ring series during the second half of the $19^{\text {th }}$ century is confirmed by

500 historical proxies showing dry conditions for the Ebro basin during the same period and a

501 strong positive NAO index at the end of the $19^{\text {th }}$ and early $20^{\text {th }}$ century (Vicente-Serrano and

502 Cuadrat 2007) and by instrumental records from Barcelona that show a dry spell from 1878 to

5031919 (Prohom et al. 2015). From 1880 to 1910 extremely low grain production was reported in

504 Spain that led to strong reductions in food availability during the first years of the $20^{\text {th }}$ century

505 and related impacts as social conflict and migrations (Vicens Vives 1985; Blanco et al. 1986). 
506 Although starvation and migration are driven by a myriad of phenomena, including political

507 and social factors, the dry period in the second half of the $19^{\text {th }}$ century may have also played a

508 role in this historically known crisis of subsistence and economic migrations due to hunger,

509 which coincided with the famous Galician, and Asturian migration to South America (Ojeda

510 and San Miguel 1985; Gómez Gómez 1996).

511 To summarise, independent sources (natural and historical) of past climate variability validate

512 our findings that attribute the non-linear moisture signals recorded by extreme tree-ring values

513 to distinct large-scale atmospheric patterns, and they allow for targeted seasonal 400-yr

514 reconstructions of summer hydroclimate for extreme wet and dry conditions independently.

\section{Conclusions}

517 An almost symmetric seasonal moisture signal was recorded during years with highest/lowest

$518 \delta^{13} \mathrm{C}$ values, with precipitation anomalies being significant for similar months (Fig. 5e). This

519 explains the robust and strong linear relationship between $\delta^{13} \mathrm{C}$ and precipitation seen in

520 correlations (Fig. 2). An opposite behaviour may render the weaker precipitation signal held by

521 the other tree-ring parameters. TRW and $\delta^{18} \mathrm{O}$ series show a much more marked seasonal

522 asymmetry in their moisture signal. These analyses of extremes revealed that high/low proxy

523 values do not necessarily correspond to mirror images in the atmospheric anomaly patterns,

524 suggesting different drivers and seasonality associated with asymmetric moisture signatures in

525 the proxies, and thus hampering the strength of their climate signal when linear approaches are

526 used (Fig. 2).

527 Severe flooding and droughts are likely to become more frequent with an intensifying water

528 cycle in a warmer world (Wentz et al. 2007; Trenberth 2011; Hartmann et al. 2013). For 
529 sustainable water resources management, information about past hydroclimatic changes are

530 needed. Our approach determining the frequency of extreme climatic conditions in the past is a

531 step forward towards a more realistic range of past climate variability considering that the

532 standard methodology based on linear regressions are biased towards the mean climate and often

533 underestimate extremes (McCarroll et al. 2015). Extreme analyses point to a better mechanistic

534 understanding of links between tree-ring proxies and large-scale atmospheric dynamics and can

535 improve climate reconstructions based on proxies with asymmetric and non-stationary signals.

536 Since this information is not available with a traditional linear approach, non-linear methods in

537 palaeoclimate research are useful to overcome the complexity of reconstructing atmospheric

538 features. The distinct seasonal signal in stable isotopes and ring-width supports multi-parameter

539 approaches for advances in the field.

540

\section{Acknowledgements}

542 We thank Oriol Bosch and Octavi Planells for their participation in sampling and laboratory

543 work. Use of the following data sets is gratefully acknowledged: Global Precipitation

544 Climatology Center data by the German Weather Service (DWD) accessed through

545 http://gpcc.dwd.de; TS by the Climate Research Unit at the University of East Anglia; NNR

546 data provided by NOAA/OAR/ESRL PSD, Boulder, Colorado, USA, through their website

547 http://www.cdc.noaa.gov; and the 20CR Project supported by the U.S. DOE, Office of Science

548 Innovative and Novel Computational Impact on Theory and Experiment program, and Office

549 of Biological and Environmental Research, and by the NOAA Climate Program Office. This

550 research was partially supported by the EU project ISONET (Contract EV K2-2001-00237)

551 and the EU FP6 project Millennium (GOCE 017008). L.A.H. was supported by the Marie 
552 Curie International Outgoing Fellowship PIOF-GA-2009-253277 grant within the FP7-

553 PEOPLE-2009-IOF program. CCU was supported by the the Penzance and John P. Chase

554 Memorial Endowed Funds and the Investment in Science Fund at WHOI.

555 


\section{REFERENCES}

557 Andreu Hayles L (2007) Climate and atmospheric CO2 effects on Iberian pine forests assessed 558 by tree-ring chronologies and their potential for climatic reconstructions. University of

$559 \quad$ Barcelona

560 Andreu L, Planells O, Gutiérrez E, Helle G, Schleser GH (2008) Climatic significance of tree-

561 ring width and $\delta^{13} \mathrm{C}$ in a Spanish pine forest network Tellus Series B-Chemical and $562 \quad$ Physical Meteorology 60:771-781

563 Andreu-Hayles L, Planells O, Gutiérrez E, Muntan E, Helle G, Anchukaitis KJ, Schleser GH

564 (2011) Long tree-ring chronologies reveal 20th century increases in water-use efficiency 565 but no enhancement of tree growth at five Iberian pine forests Global Change Biology

$566 \quad$ 17:2095-2112 doi:10.1111/j.1365-2486.2010.02373.x

567 Barbour MM (2007) Stable oxygen isotope composition of plant tissue: a review Functional

$568 \quad$ Plant Biology 34:83-94 doi:http://dx.doi.org/10.1071/FP06228

569 Barriendos M (1997) Climatic variations in the Iberian Peninsula during the late Maunder

570 Minimum (AD 1675-1715): an analysis of data from rogation ceremonies The Holocene

$571 \quad 7: 105-111$ doi:10.1177/095968369700700110

572 Barriendos M, Llasat MC (2003) The Case of the 'Maldá' Anomaly in the Western

573 Mediterranean Basin (AD 1760-1800): An Example of a Strong Climatic Variability

$574 \quad$ Climatic Change 61:191-216 doi:10.1023/a:1026327613698

575 Barriendos M, Martin-Vide J (1998) Secular Climatic Oscillations as Indicated by Catastrophic

576 Floods in the Spanish Mediterranean Coastal Area (14th-19th Centuries) Climatic

$577 \quad$ Change 38:473-491 doi:10.1023/a:1005343828552 
578 Barriendos M, Rodrigo FS (2006) Study of historical flood events on Spanish rivers using 579 documentary data Hydrological Sciences Journal 51:765-783 doi:10.1623/hysj.51.5.765

580 Bladé I, Liebmann B, Fortuny D, Oldenborgh GJ (2011) Observed and simulated impacts of the

581 summer NAO in Europe: implications for projected drying in the Mediterranean region $582 \quad$ Climate Dynamics 39:709-727 doi:10.1007/s00382-011-1195-x

583 Blanco A et al. (1986) Historia de España, . Historia 16, ISBN 84-85229-81-9 edn., Madrid

584 Borella S, Leuenberger M, Saurer M (1999) Analysis of delta O-18 in tree rings: Wood-cellulose 585 comparison and method dependent sensitivity Journal of Geophysical Research$586 \quad$ Atmospheres 104:19267-19273

587 Buntgen U, Frank D, Grudd H, Esper J (2008) Long-term summer temperature variations in the $588 \quad$ Pyrenees Climate Dynamics 31:615-631 doi:10.1007/s00382-008-0390-x

589 Buwen D, Rowan TS, Tim W, Kevin H (2013) Variability of the North Atlantic summer storm 590 track: mechanisms and impacts on European climate Environmental Research Letters $591 \quad 8: 034037$

592 Cai W, Cowan T, Thatcher M (2012) Rainfall reductions over Southern Hemisphere semi-arid 593 regions: the role of subtropical dry zone expansion Scientific Reports 2 $594 \quad$ doi:10.1038/srep00702

595 Camuffo D et al. (2013) Western Mediterranean precipitation over the last 300 years from 596 instrumental observations Climatic Change 117:85-101 doi:10.1007/s10584-012-0539-9

597 Compo GP et al. (2011) The Twentieth Century Reanalysis Project Quarterly Journal of the $598 \quad$ Royal Meteorological Society 137:1-28 doi:10.1002/qj.776 
599 Cook ER, D'Arrigo RD, Mann ME (2002) A Well-Verified, Multiproxy Reconstruction of the

600 Winter North Atlantic Oscillation Index since a.d. 1400* Journal of Climate 15:1754$601 \quad 1764$ doi:10.1175/1520-0442(2002)015<1754:awvmro $>2.0 . c o ; 2$

602 Cook ER, Kairiukstis L (1990) Methods of Dendrochronology in Applications in the 603 Environmental Sciences Kluwer, Dordrecht, 394 pp.,

604 Cook ER, Peters K (1997) Calculating unbiased tree-ring indices for the study of climatic and 605 environmental change Holocene 7:359-368

606 Cook ER et al. (2015) Old World megadroughts and pluvials during the Common Era Science $607 \quad$ Advances 1 doi:10.1126/sciadv.1500561

608 De Luis M, Carlos Gonzalez-Hidalgo J, Longares LA, Stepanek P (2009) Seasonal precipitation 609 trends in the Mediterranean Iberian Peninsula in second half of 20th century Int $\mathrm{J}$ $610 \quad$ Climatol 29:1312-1323 doi:10.1002/joc.1778

611 Domínguez-Castro F, García-Herrera R, Ribera P, Barriendos M (2010) A shift in the spatial 612 pattern of Iberian droughts during the 17th century Clim Past 6:553-563 doi:10.5194/cp-

614 Domínguez-Castro F, Ribera P, García-Herrera R, Vaquero JM, Barriendos M, Cuadrat JM, 615 Moreno JM (2012) Assessing extreme droughts in Spain during 1750-1850 from 616 rogation ceremonies Clim Past 8:705-722 doi:10.5194/cp-8-705-2012

617 Dominguez-Castro F, Santisteban JI, Barriendos M, Mediavilla R (2008) Reconstruction of 618 drought episodes for central Spain from rogation ceremonies recorded at the Toledo 619 Cathedral from 1506 to 1900: A methodological approach Global and Planetary Change $620 \quad 63: 230-242$ doi:10.1016/j.gloplacha.2008.06.002 
621 Dorado Liñán I et al. (2012) Estimating 750 years of temperature variations and uncertainties in

622 the Pyrenees by tree-ring reconstructions and climate simulations Clim Past 8:919-933

623 doi:10.5194/cp-8-919-2012

624 Dorado Liñan I, Gutiérrez E, Andreu-Hayles L, Heinrich I, Helle G (2012) Potential to explain

625 climate from tree rings in the south of the Iberian Peninsula Climate Research 55:121-

$626 \quad 136$ doi:10.3354/cr01126

627 Dorado Liñán I et al. (2011) Pooled versus separate measurements of tree-ring stable isotopes

$628 \quad$ Science of The Total Environment 409:2244-2251

629 Dorado Liñán I et al. (2015) Eight-hundred years of summer temperature variations in the 630 southeast of the Iberian Peninsula reconstructed from tree rings Climate Dynamics 44:75$631 \quad 93$ doi:10.1007/s00382-014-2348-5

632 Esper J et al. (2015) Atlantic and Mediterranean synoptic drivers of central Spanish juniper 633 growth Theoretical and Applied Climatology 121:571-579 doi:10.1007/s00704-014$634 \quad 1254-4$

635 Farquhar GD, O'Leary MH, Berry JA (1982) On the Relationship between Carbon Isotope 636 Discrimination and the Intercellular Carbon Dioxide Concentration in Leaves Australian 637 Journal of Plant Physiology 9:121-137

638 Fernández A, Génova M, Creus J, Gutiérrez E (1996) Dendroclimatological investigations 639 covering the last 300 years in Central Spain. . In: Tree Rings, Environment and Humanity 640 (eds. Dean JS, Meko DM, Swetman TW), pp. 181-190 RADIOCARBON. 889 pp.

641 Frank DC et al. (2015) Water-use efficiency and transpiration across European forests during the 642 Anthropocene Nature Clim Change 5:579-583 doi:10.1038/nclimate2614 
645 Friedman JH (1984) A variable span scatterplot smoother. Laboratory for Computational 646 Statistics. Stanford University Technical Report No. 5.

647 Fritts H (1976) Tree rings and climate. Academic Press, New York, 433 pp.,

648 Gagen M, McCarroll D, Jalkanen R, Loader NJ, Robertson I, Young GHF (2012) A rapid 649 method for the production of robust millennial length stable isotope tree ring series for

García Antón M, Franco Múgica F, Maldonado J, Morla Juaristi C, Sainz Ollero H (1997) New data concerning the evolution of the vegetation in Lillo pinewood (Leon, Spain) J Biogeogr 24:929-934 doi:10.1046/j.1365-2699.1997.00181.x

Giorgi F (2006) Climate change hot-spots Geophys Res Lett 33

Giorgi F, Lionello P (2008) Climate change projections for the Mediterranean region Global and Planetary Change 63:90-104

660 Hartmann DL et al. (2013) Observations: Atmosphere and Surface. In: Stocker TF, D. Qin, G.-K.

Gómez Gómez P (1996) De Asturias a América, Cuba (1850-1930): la comunidad asturiana de Plattner, M. Tignor, S.K. Allen, J. Boschung, A. Nauels, Y. Xia, V. Bex and P.M. Midgley (eds.) (ed) Climate Change 2013: The Physical Science Basis. Contribution of 
666 Hernández A et al. (2015) Sensitivity of two Iberian lakes to North Atlantic atmospheric 667 circulation modes Climate Dynamics 45:3403-3417 doi:10.1007/s00382-015-2547-8

668 Hoerling $M$ et al. (2012) Anatomy of an Extreme Event Journal of Climate 26:2811-2832 669 doi:10.1175/jcli-d-12-00270.1

670 Hurrell JW (1995) Decadal Trends in the North Atlantic Oscillation: Regional Temperatures and $671 \quad$ Precipitation Science 269:676-679

672 Kalnay E et al. (1996) The NCEP/NCAR 40-Year Reanalysis Project Bulletin of the American 673 674 Meteorological Society $77: 437-471$ doi:10.1175/15200477(1996)077<0437:tnyrp >2.0.co;2

675 Karnauskas KB, Ummenhofer CC (2014) On the dynamics of the Hadley circulation and 676 subtropical drying Climate Dynamics 42:2259-2269 doi:10.1007/s00382-014-2129-1

677 Kistler R et al. (2001) The NCEP-NCAR 50-Year Reanalysis: Monthly Means CD-ROM and 678 Documentation Bulletin of the American Meteorological Society 82:247-267 679 doi:10.1175/1520-0477(2001)082<0247:tnnyrm>2.3.co;2

680 Konter O, Holzkämper S, Helle G, Büntgen U, Saurer M, Esper J (2014) Climate sensitivity and 681 682 parameter coherency in annually resolved $\delta 13 \mathrm{C}$ and $\delta 18 \mathrm{O}$ from Pinus uncinata tree-ring data in the Spanish Pyrenees Chemical Geology 377:12-19

684 Labuhn I et al. (2014) Tree age, site and climate controls on tree ring cellulose $\delta 18 \mathrm{O}$ : A case 685 study on oak trees from south-western France Dendrochronologia 32:78-89 686 doi:http://dx.doi.org/10.1016/i.dendro.2013.11.001

687 Lau WKM, Kim KM (2015) Robust Hadley Circulation changes and increasing global dryness 688 due to $\mathrm{CO} 2$ warming from CMIP5 model projections Proceedings of the National 

doi:10.1073/pnas. 1418682112

691 Laumer W, Andreu L, Helle G, Schleser GH, Wieloch T, Wissel H (2009) A novel approach for 692 the homogenization of cellulose to use micro-amounts for stable isotope analyses Rapid 693 Communications in Mass Spectrometry 23:1934-1940

694 Leavitt SW, Long A (1984) Sampling strategy for stable carbon isotope analyses of tree rings in 695 pine Nature 311:145-147

696 Lehmann J, Coumou D (2015) The influence of mid-latitude storm tracks on hot, cold, dry and 697 wet extremes Scientific Reports 5:17491 doi:10.1038/srep17491

698 http://www.nature.com/articles/srep17491 - supplementary-information

699 Linderholm HW, Folland CK, Walther A (2009) A multicentury perspective on the summer 700 North Atlantic Oscillation (SNAO) and drought in the eastern Atlantic Region Journal of $701 \quad$ Quaternary Science 24:415-425 doi:10.1002/jqs.1261

702 Llamas MR (2003) Lessons learnt from from the impact of the neglected role of groundwater in 703 Spain's water policy. Water Resources Perspectives: Evaluation, Management, and Policy, A. S. Sharhan and W. W. Wood, Eds., Elsevier Science, Amsterdam, 63-81.

705 Llasat M-C, Barriendos M, Barrera A, Rigo T (2005) Floods in Catalonia (NE Spain) since the 706 14th century. Climatological and meteorological aspects from historical documentary 707 sources and old instrumental records Journal of Hydrology 313:32-47 708 doi:http://dx.doi.org/10.1016/i.jhydrol.2005.02.004

709 Loader NJ, Robertson I, Barker AC, Switsur VR, Waterhouse JS (1997) An improved technique 710 for the batch processing of small wholewood samples to $\alpha$-cellulose Chemical Geology 711 $136: 313-317$ 
712 Loader NJ, Young GHF, Grudd H, McCarroll D (2013) Stable carbon isotopes from Torneträsk,

713 northern Sweden provide a millennial length reconstruction of summer sunshine and its

714 relationship to Arctic circulation Quaternary Science Reviews 62:97-113

715 doi:http://dx.doi.org/10.1016/i.quascirev.2012.11.014

716 López-Moreno JI, Beguería S, Vicente-Serrano SM, García-Ruiz JM (2007) Influence of the

717 North Atlantic Oscillation on water resources in central Iberia: Precipitation, streamflow

718 anomalies, and reservoir management strategies Water Resources Research 43:W09411

719 doi:10.1029/2007wr005864

720 Lu J, Deser C, Reichler T (2009) Cause of the widening of the tropical belt since 1958

$721 \quad$ Geophysical Research Letters 36 doi:10.1029/2008g1036076

722 Lu J, Vecchi GA, Reichler T (2007) Expansion of the Hadley cell under global warming

723 Geophysical Research Letters 34:L06805 doi:10.1029/2006g1028443

724 Luterbacher J et al. (2000) Monthly mean pressure reconstruction for the Late Maunder

725 Minimum Period (AD 1675-1715) Int J Climatol 20:1049-1066 doi:10.1002/1097-

$726 \quad$ 0088(200008)20:10<1049::aid-joc521>3.0.co;2-6

727 Luterbacher J et al. (2002) Reconstruction of sea level pressure fields over the Eastern North

728 Atlantic and Europe back to 1500 Climate Dynamics 18:545-561 doi:10.1007/s00382-

$729 \quad 001-0196-6$

730 Manrique E, Fernandez-Cancio A (2000) Extreme climatic events in dendroclimatic 731 reconstructions from spain Climatic Change 44:123-138

732 McCarroll D et al. (2009) Correction of tree ring stable carbon isotope chronologies for changes

733 in the carbon dioxide content of the atmosphere Geochimica Et Cosmochimica Acta

$734 \quad 73: 1539-1547$ doi:10.1016/j.gca.2008.11.041 
735 McCarroll D, Loader NJ (2004) Stable isotopes in tree rings Quaternary Research Reviews $736 \quad 23: 771-801$

737 McCarroll D, Pawellek F (1998) Stable carbon isotope ratios of latewood cellulose in Pinus

738 sylvestris from northern Finland: variability and signal-strength Holocene 8:675-684 739 doi: $10.1191 / 095968398675987498$

740 McCarroll D, Young GH, Loader NJ (2015) Measuring the skill of variance-scaled climate 741 reconstructions and a test for the capture of extremes The Holocene 25:618-626 $742 \quad$ doi:10.1177/0959683614565956

743 Meko DM, Touchan R, Anchukaitis KJ (2011) Seascorr: A MATLAB program for identifying 744 the seasonal climate signal in an annual tree-ring time series Computers \& Geosciences 745 37:1234-1241 doi:http://dx.doi.org/10.1016/i.cageo.2011.01.013

746 Melvin TM, Briffa KR (2008) A "signal-free" approach to dendroclimatic standardisation $747 \quad$ Dendrochronologia 26:71-86

748 Mitchell TD, Jones PD (2005) An improved method of constructing a database of monthly 749 climate observations and associated high-resolution grids Int J Climatol 25:693-712

750 Naulier M et al. (2015) A millennial summer temperature reconstruction for northeastern Canada 751 using oxygen isotopes in subfossil trees Clim Past 11:1153-1164 doi:10.5194/cp-11$752 \quad 1153-2015$

753 Nicault A, Alleaume S, Brewer S, Carrer M, Nola P, Guiot J (2008) Mediterranean drought 754 fluctuation during the last 500 years based on tree-ring data Climate Dynamics 31:227$755 \quad 245$ doi:10.1007/s00382-007-0349-3

756 Ojeda G, San Miguel JL (1985) Campesinos, emigrantes, indianos Emigración y economía en 757 Asturias, 1830-1930. . Salinas, Ed. Ayalga. ISBN 84-7411-132-3., 
758 Orden Martín R (2013) El pinar de Lillo. Bedia Artes Gráficas, S. C. Santander (Cantabria, 759 Spain), 90 pp. ISBN: 978-84-695-6855-2.

760 Pauling A, Luterbacher J, Casty C, Wanner H (2006) Five hundred years of gridded high761 resolution precipitation reconstructions over Europe and the connection to large-scale $762 \quad$ circulation Climate Dynamics 26:387-405

763 Planells O, Gutiérrez E, Helle G, Schleser G (2009) A forced response to twentieth century 764 climate conditions of two Spanish forests inferred from widths and stable isotopes of tree 765 rings Climatic Change 97:229-252 doi:10.1007/s10584-009-9602-6

766 Previdi M, Liepert BG (2007) Annular modes and Hadley cell expansion under global warming $767 \quad$ Geophysical Research Letters 34:L22701 doi:10.1029/2007g1031243

768 Prohom M, Barriendos M, Sanchez-Lorenzo A (2015) Reconstruction and homogenization of the 769 longest instrumental precipitation series in the Iberian Peninsula (Barcelona, 1786-2014) $770 \quad$ Int J Climatol:n/a-n/a doi:10.1002/joc.4537

771 Rodó X, Baert E, Comin FA (1997) Variations in seasonal rainfall in Southern Europe during the 772 present century: relationship with the North Atlantic Oscillation and the El Niño773 Southern Oscillation Climate Dynamics 13:275-284

774 Rodrigo FS, Barriendos M (2008) Reconstruction of seasonal and annual rainfall variability in 775 the Iberian peninsula (16th-20th centuries) from documentary data Global and Planetary 776 Change 63:243-257 doi:http://dx.doi.org/10.1016/i.gloplacha.2007.09.004

777 Rodriguez-Puebla C, Encinas AH, Nieto S, Garmendia J (1998) Spatial and temporal patterns of 778 annual precipitation variability over the Iberian Peninsula Int J Climatol 18:299-316 779 doi:10.1002/(sici)1097-0088(19980315)18:3<299::aid-joc247>3.0.co;2-1 
780 Ruiz-Bellet JL, Balasch JC, Tuset J, Barriendos M, Mazon J, Pino D (2015) Historical, 781 hydraulic, hydrological and meteorological reconstruction of 1874 Santa Tecla flash 782 floods in Catalonia (NE Iberian Peninsula) Journal of Hydrology 524:279-295 783 doi:http://dx.doi.org/10.1016/i.jhydrol.2015.02.023

784 Saurer M, Schweingruber F, Vaganov EA, Shiyatov SG, Siegwolf R (2002) Spatial and temporal 785 oxygen isotope trends at the northern tree-line in Eurasia Geophysical Research Letters 29:7-1-7-4 doi:10.1029/2001GL013739

787 Saurer M et al. (2014) Spatial variability and temporal trends in water-use efficiency of 788 European forests Global Change Biology 20:3700-3712 doi:10.1111/gcb.12717

789 Schneider U, Becker A, Finger P, Meyer-Christoffer A, Ziese M, Rudolf B (2014) GPCC's new

790 land surface precipitation climatology based on quality-controlled in situ data and its role 791 in quantifying the global water cycle Theoretical and Applied Climatology 115:15-40 792 doi:10.1007/s00704-013-0860-x

793 Seftigen K, Linderholm HW, Loader NJ, Liu Y, Young GHF (2011) The influence of climate on $79413 \mathrm{C} / 12 \mathrm{C}$ and $18 \mathrm{O} / 16 \mathrm{O}$ ratios in tree ring cellulose of Pinus sylvestris L. growing in the 795 central Scandinavian Mountains Chemical Geology 286:84-93 796 doi:http://dx.doi.org/10.1016/j.chemgeo.2011.04.006

797 Tejedor E, de Luis M, Cuadrat J, Esper J, Saz M (2015) Tree-ring-based drought reconstruction 798 in the Iberian Range (east of Spain) since 1694 International Journal of 799 Biometeorology:1-12 doi:10.1007/s00484-015-1033-7

800 Trenberth K (2011) Changes in precipitation with climate change Climate Research 47:123-138 801 doi:10.3354/cr00953 
802 Treydte K et al. (2007) Signal strength and climate calibration of a European tree-ring isotope 803 network Geophysical Research Letters 34:L24302 doi:10.1029/2007g1031106

804 Trigo RM, Pozo-Vázquez D, Osborn TJ, Castro-Díez Y, Gámiz-Fortis S, Esteban-Parra MJ 805 (2004) North Atlantic oscillation influence on precipitation, river flow and water 806 resources in the Iberian Peninsula Int J Climatol 24:925-944 doi:10.1002/joc.1048

807 Trigo RM, Valente MA, Trigo IF, Miranda PMA, Ramos AM, Paredes D, García-Herrera R 808 (2008) The Impact of North Atlantic Wind and Cyclone Trends on European 809 Precipitation and Significant Wave Height in the Atlantic Annals of the New York $810 \quad$ Academy of Sciences 1146:212-234 doi:10.1196/annals.1446.014

811 Vicens Vives J (1985) Historia económica de España. In., ISBN 84-316-1106-5. edn. Vicens 812 Vives Ed. , Barcelona, 8th edition, p 782

813 Vicente-Serrano SM (2006) Spatial and temporal analysis of droughts in the Iberian Peninsula 814 (1910-2000) Hydrological Sciences Journal 51:83-97 doi:10.1623/hysj.51.1.83

815 Vicente-Serrano SM, Cuadrat JM (2007) North Atlantic oscillation control of droughts in north816 east Spain: evaluation since 1600 A. D Climatic Change 85:357-379 doi:10.1007/s10584$817 \quad 007-9285-9$

818 Vicente-Serrano SM, López-Moreno JI (2008) Nonstationary influence of the North Atlantic 819 Oscillation on European precipitation Journal of Geophysical Research: Atmospheres $820 \quad$ 113:D20120 doi:10.1029/2008jd010382

821 Wentz FJ, Ricciardulli L, Hilburn K, Mears C (2007) How much more rain will global warming 822 bring? Science 317:233-235 doi:10.1126/science.1140746 
823 Wigley TML, Briffa KR, Jones PD (1984) On the Average Value of Correlated Time Series, 824 with Applications in Dendroclimatoly and Hydrometeorology Journal of Climate and $825 \quad$ Applied Meteorology 23:201-213

826 Young GHF et al. (2015) Oxygen stable isotope ratios from British oak tree-rings provide a 827 strong and consistent record of past changes in summer rainfall Climate Dynamics $828 \quad 45: 3609-3622$ doi: $10.1007 / \mathrm{s} 00382-015-2559-4$

829

830 
832 TABLES

833 Table 1 Years with extreme values in the top and bottom deciles (10\%): the ranked 8 highest

834 and 8 lowest values for the time-series of the Lillo tree-ring chronologies for the period 1925-

8352002 for (left) TRW, (middle) $\delta^{13} \mathrm{C}$, and (right) $\delta^{18} \mathrm{O}$. The lowest of the uppermost decile and

836 the highest of the lowermost decile of the proxy values are highlighted in grey and were used

837 as thresholds for analyses in the pre-instrumental period.

\begin{tabular}{llllll}
\hline \multicolumn{6}{c}{ Wet years } \\
\hline Year & High TRW & Year & Low d13C & Year & Low d180 \\
\hline 1959 & 1.30 & 1958 & -22.62 & 1930 & 29.60 \\
1955 & 1.29 & 1930 & -22.63 & 1953 & 29.53 \\
1973 & 1.27 & 1977 & -22.65 & 1957 & 29.38 \\
1956 & 1.24 & 1966 & -22.66 & 1931 & 29.26 \\
1971 & 1.24 & 1932 & -22.69 & 1925 & 29.22 \\
1958 & 1.21 & 1925 & -22.70 & 1932 & 29.16 \\
1953 & 1.21 & 1952 & -22.71 & 1952 & 28.97 \\
1936 & 1.21 & 1931 & -22.86 & 1977 & 28.46 \\
\hline \multicolumn{7}{c}{ Dry years } & & \\
\hline Year & Low TRW & Year & High d13C & Year & High d180 \\
\hline 1948 & 0.87 & 1991 & -20.67 & $\mathbf{2 0 0 1}$ & 32.71 \\
1982 & 0.86 & 1994 & -20.91 & 2002 & 32.18 \\
2001 & 0.84 & 1999 & -20.95 & 1986 & 32.12 \\
1986 & 0.83 & 1989 & -20.97 & 1958 & 32.08 \\
1983 & 0.83 & 2001 & -20.99 & 1963 & 32.08 \\
1925 & 0.80 & 1986 & -21.04 & 1990 & 32.06 \\
1991 & 0.80 & 1990 & -21.04 & 1995 & 32.00 \\
1984 & 0.79 & 1979 & -21.11 & 1965 & 31.95 \\
\hline
\end{tabular}

838

839 
840 Table 2 Years with extreme values in the top and bottom deciles (10\%): the 23 highest and 23

841 lowest values for the time-series of the Lillo tree-ring chronologies for the period 1665-1900

842 for (left) TRW, (middle) $\delta^{13} \mathrm{C}$, and (right) $\delta^{18} \mathrm{O}$. Years with proxy values above or below the

843 thresholds (horizontal lines in Fig. 3) established in the instrumental period (1925-2002) by the

844 lowest of the uppermost decile and the highest of the lowermost decile of the proxy values

845 (Table 1) are indicated: (a) grey boxes: when those years overlapped with the 23 years within

846 the deciles; (b) listed at the end just for TRW: when those years are different from the 23 years

847 within the deciles.

848

\begin{tabular}{lll|lll}
\hline \multicolumn{3}{c}{ Wet years } & \multicolumn{3}{c}{ Dry years } \\
\hline High TRW & Low d13C & Low d180 & Low TRW & High d13C & High d180 \\
\hline \multicolumn{1}{c}{ (a) Years with extreme values in the top/bottom decils } & $(10 \%)$ from 1665 to 1900 \\
\hline 1672 & 1708 & 1684 & 1705 & 1669 & 1670 \\
1673 & 1721 & 1714 & 1706 & 1674 & 1686 \\
1680 & 1747 & 1745 & 1707 & 1678 & 1696 \\
1682 & 1749 & 1747 & 1709 & 1680 & 1699 \\
1690 & 1756 & 1749 & 1741 & 1681 & 1700 \\
1691 & 1758 & 1755 & 1756 & 1682 & 1702 \\
1692 & 1801 & 1768 & 1767 & 1683 & 1705 \\
1693 & 1808 & 1788 & 1768 & 1688 & 1730 \\
1694 & 1809 & 1799 & 1769 & 1694 & 1738 \\
1715 & 1825 & 1800 & 1770 & 1696 & 1741 \\
1718 & 1826 & 1806 & 1771 & 1703 & 1748 \\
1734 & 1836 & 1823 & 1800 & 1712 & 1753 \\
1737 & 1841 & 1843 & 1803 & 1716 & 1784 \\
1866 & 1843 & 1845 & 1804 & 1726 & 1785 \\
1867 & 1845 & 1849 & 1806 & 1729 & 1824 \\
1868 & 1849 & 1853 & 1824 & 1731 & 1828 \\
1869 & 1850 & 1854 & 1826 & 1738 & 1868 \\
1870 & 1852 & 1855 & 1841 & 1771 & 1870 \\
1871 & 1858 & 1878 & 1844 & 1776 & 1873 \\
1878 & 1877 & 1880 & 1845 & 1778 & 1874 \\
1881 & 1885 & 1883 & 1849 & 1817 & 1881 \\
1892 & 1887 & 1885 & 1855 & 1832 & 1898 \\
1893 & 1888 & 1889 & 1856 & 1898 & 1899 \\
\hline & & & & &
\end{tabular}


(b) Years with extreme values outside the decile range (10\%) from 1665 to 1900

\begin{tabular}{l|l}
\hline 1670,1681 & 1705,1706 \\
1684,1695 & 1707,1708 \\
1696,1727 & 1723,1724 \\
1730,1762 & 1755,1757 \\
1882 & 1801,1817 \\
& 1823,1827 \\
& 1836,1840 \\
& 1842 \\
\hline
\end{tabular}

849 
1

\section{0 years of summer hydroclimate from stable isotopes in Iberian trees}

\author{
Gerd Helle, Gerhard H. Schleser, Markus Leuenberger, Emilia Gutiérrez \\ Laia Andreu-Hayles * \\ Caroline C. Ummenhofer, Mariano Barriendos \\ AND EDWARD R. COOK
}

FIGURES

under revision in Climate Dynamics

${ }^{*}$ Corresponding author address: Laia Andreu-Hayles, Tree-Ring Laboratory, Lamont-Doherty Earth Observatory, Columbia University, Palisades, NY, USA; lah@ldeo.columbia.edu 


\section{List of Figures}

$7 \quad 1$ Mean observed annual precipitation $(\mathrm{mm})$ in the Iberian Peninsula for the period 1901-2002: The Lillo study site (star) and other key locations are indicated. Red dashed box delimits the target region used to create the Lillo precipitation and temperature time series used in this study.

2 Correlations for monthly precipitation and partial correlations for temperature, both from October in the previous year to September of the current year for the period 1925-2002 with tree-ring parameters for (left) TRW, (middle) $\delta^{13} \mathrm{C}$, and (right) $\delta^{18} \mathrm{O}$. Note that coloured bars indicate significant correlation coefficients at the $95 \%$ confidence level.

3 Time-series of the Lillo tree-ring chronologies for the period 1600-2002 for (a) TRW, (b) $\delta^{13} \mathrm{C}$, and (c) $\delta^{18} \mathrm{O}$. The circles in the period from 1665 to 1900 show the years with extreme values in the top and bottom deciles of the proxy times-series: the 23 highest and 23 lowest values (Table 2). Filled circles indicate that the values are above or below the thresholds (horizontal lines) established in the instrumental period by the lowest of the uppermost decile and the highest of the lowermost decile of the proxy values in the analysis period 1925-2002 (Table 1). Dashed lines delineate the studied preinstrumental period from 1665 to 1900 and the instrumental period from 1925 to 2002 used for the analyses shown in Figs. 5-7

4 Box-and-whisker plots for the values of the tree-ring records during the 8 years of extreme high/low values for each tree-ring records: (left) TRW, (middle) $\delta^{13} \mathrm{C}$ and (right) $\delta^{18} \mathrm{O}$. The red line represents the median, the blue boxes delimit the 25 th and 75 th percentile (i.e. interquartile range) and whiskers the minimum and maximum values. 
Lillo tree-ring series and seasonal cycles for precipitation and temperature: (a-c) Time-series of the Lillo tree-ring chronologies for the period 1925-2002 for (left) TRW, (middle) $\delta^{13} \mathrm{C}$, and (right) $\delta^{18} \mathrm{O}$. Annual values are shown in black, 5-year moving average in green, and years with extreme high and low values in the time-series highlighted with filled circles. (d-i) Average seasonal cycle (grey shading) and seasonal cycles during years with the extreme proxy values detected in (a-c) shown with coloured lines for (d-f) Lillo precipitation and (g-i) Lillo temperature. Where the coloured lines lie outside the grey shading, significant deviations from average conditions occur.

6 Composites of wet summer conditions during years with extreme values in the tree-ring series in the studied instrumental period (1925-2002). Note that wet conditions correspond to wide (high) values in TRW and low values for both stable isotopic ratios $\left(\delta^{13} \mathrm{C}\right.$ and $\left.\delta^{18} \mathrm{O}\right)$. (a-l): Seasonal composite anomalies for years with extreme proxy values are shown for those months with significant deviations in the precipitation seasonal cycle (Fig. 5d-f) for (ac) precipitation, (d-f) surface air temperature (SAT), (g-i) moisture transport integrated below 500hPa, and (j-l) Sea Level Pressure (SLP). Dashed contours and black arrows indicate anomalies significant at the $90 \%$ confidence level.

7 Composites of dry summer conditions during years with extreme values in the tree-ring series for the studied instrumental period (1925-2002). Note that dry conditions correspond to narrow (low) values in TRW and high values for both stable isotopic ratios $\left(\delta^{13} \mathrm{C}\right.$ and $\left.\delta^{18} \mathrm{O}\right)$. (a-l): Seasonal composite anomalies for years with extreme proxy values are shown for those months with significant deviations in the precipitation seasonal cycle (Fig. 5d-f) for (a-c) precipitation, (d-f) surface air temperature (SAT), (g-i) moisture transport integrated below 500hPa, and (j-l) Sea Level Pressure (SLP). Dashed contours and black arrows indicate anomalies significant at the $90 \%$ level. 
8 Seasonal composite analyses of SLP (mb) during years with extreme values in the tree-ring series for the pre-instrumental period (1665-1900). Note that wet conditions over the Lillo site correspond to wide (high) values in TRW (a) and low values for both stable isotopic ratios $\delta^{13} \mathrm{C}(\mathrm{b})$ and $\delta^{18} \mathrm{O}(\mathrm{c})$; dry conditions to narrow (low) values in TRW (d) and high values for both stable isotopic ratios $\delta^{13} \mathrm{C}(\mathrm{e})$ and $\delta^{18} \mathrm{O}(\mathrm{f})$. $\mathrm{n}$ indicates the number of extreme years used in each composite that was based on the criteria to select years above and below the threshold established in Fig. 3 .

9 As Fig. 8, but for the self-calibrating Palmer Drought Severity Index (scPDSI) from the Old World Drought Atlas.

10 As Fig. 8, but using the years detected by the 8 high / low proxy values for the instrumental period (1925-1999) for the SLP anomaly composites. n indicates the number of extreme years used in each composite. Note that 7 years were used instead of 8 in some cases when the year 2001 needed to be excluded because it was not available in the SLP gridded product.

11 As Fig. 8, but using the years detected by the 8 high / low proxy values from the instrumental period (1925-2002) for the scPDSI anomaly composites.

12 Time-series of the number of extreme events in 20-yr sliding windows for the extreme values in both $\delta^{13} \mathrm{C}$ and $\delta^{18} \mathrm{O}$ records. Wet (dry) conditions are reflected by low (high) isotopic extreme values. 


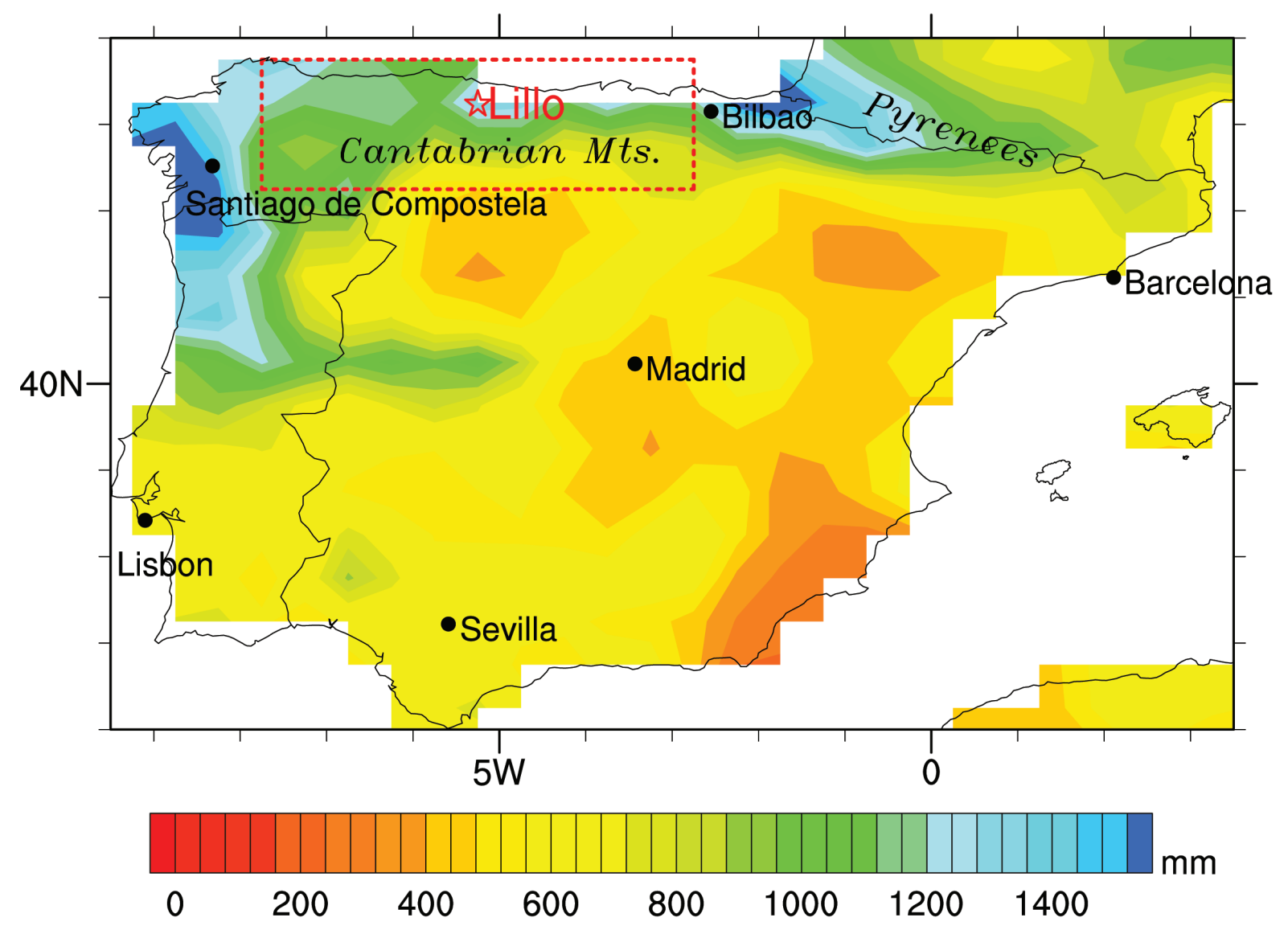

FIG. 1. Mean observed annual precipitation ( $\mathrm{mm}$ ) in the Iberian Peninsula for the period 1901-2002: The Lillo study site (star) and other key locations are indicated. Red dashed box delimits the target region used to create the Lillo precipitation and temperature time series used in this study. 


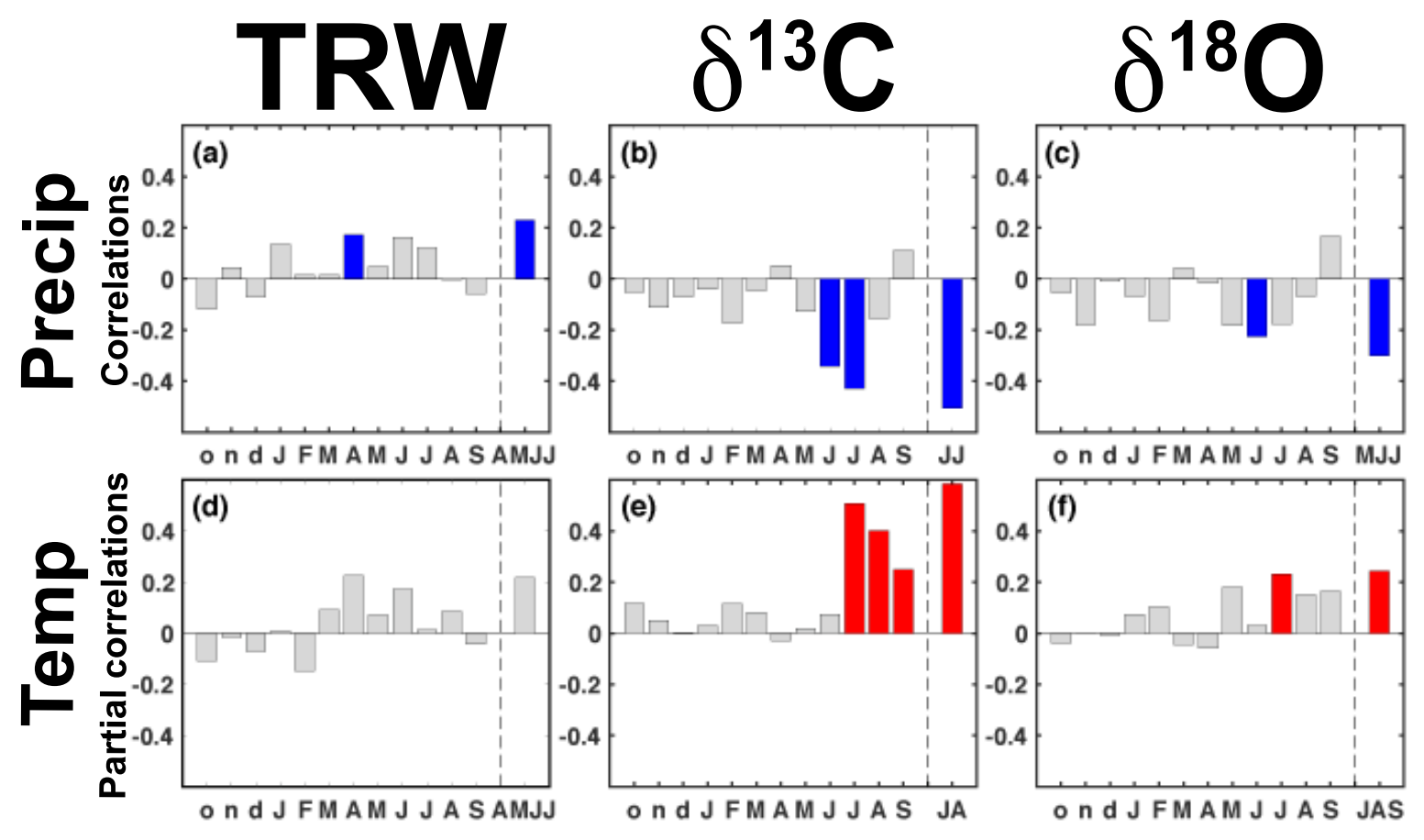

FIG. 2. Correlations for monthly precipitation and partial correlations for temperature, both from October in the previous year to September of the current year for the period 1925-2002 with tree-ring parameters for (left) TRW, (middle) $\delta^{13} \mathrm{C}$, and (right) $\delta^{18} \mathrm{O}$. Note that coloured bars indicate significant correlation coefficients at the $95 \%$ confidence level. 
(a)

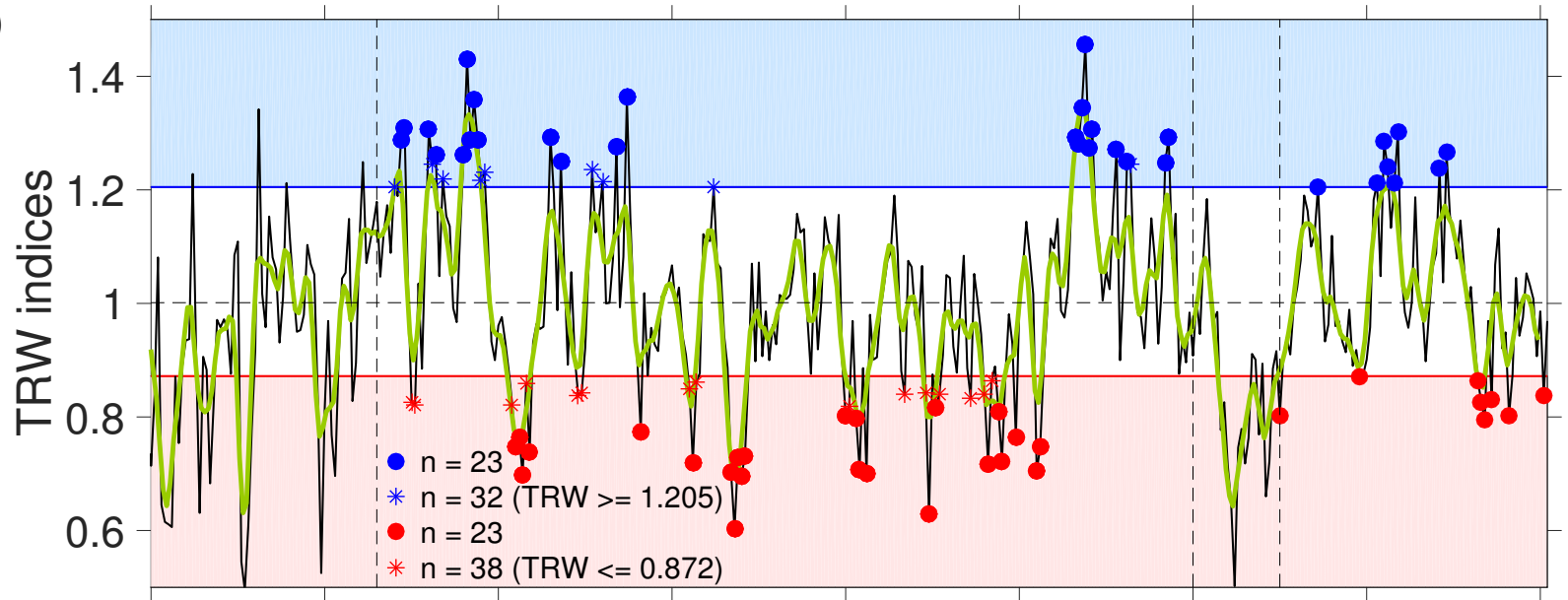

(b) $-20.5 \quad \begin{array}{lllllllll}1600 & 1650 & 1700 & 1750 & 1800 & 1850 & 1900 & 1950 & 2000\end{array}$

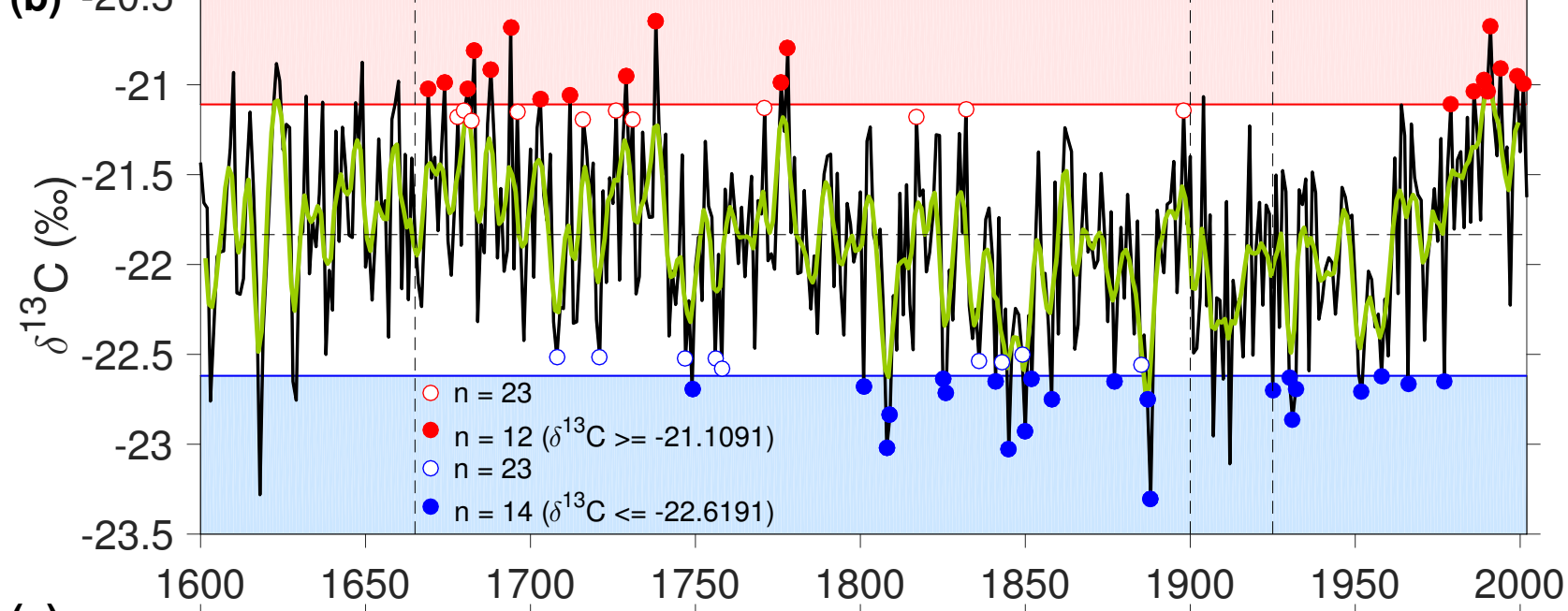

(c)

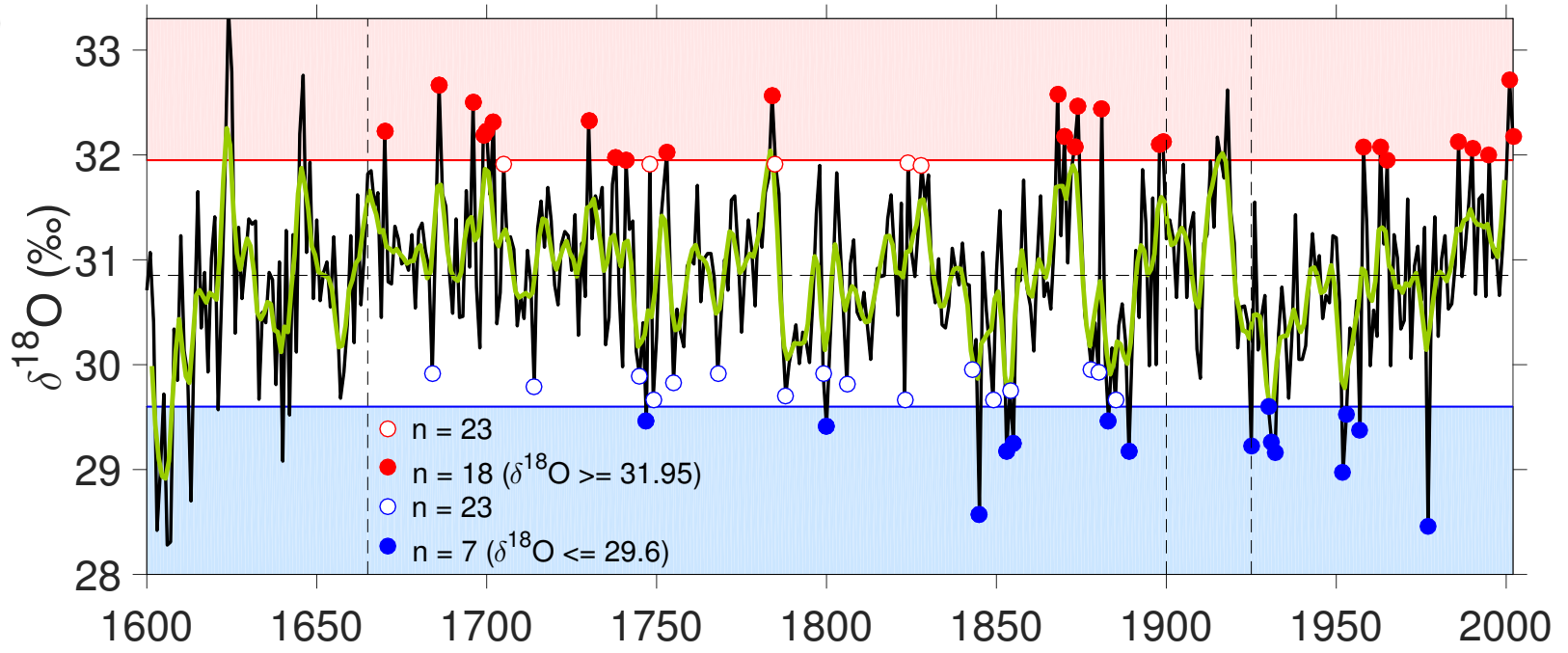


FIG. 3. Time-series of the Lillo tree-ring chronologies for the period 1600-2002 for (a) TRW, (b) $\delta^{13} \mathrm{C}$, and (c) $\delta^{18} \mathrm{O}$. The circles in the period from 1665 to 1900 show the years with extreme values in the top and bottom deciles of the proxy times-series: the 23 highest and 23 lowest values (Table 2). Filled circles indicate that the values are above or below the thresholds (horizontal lines) established in the instrumental period by the lowest of the uppermost decile and the highest of the lowermost decile of the proxy values in the analysis period 1925-2002 (Table 1). Dashed lines delineate the studied pre-instrumental period from 1665 to 1900 and the instrumental period from 1925 to 2002 used for the analyses shown in Figs. 5-7 

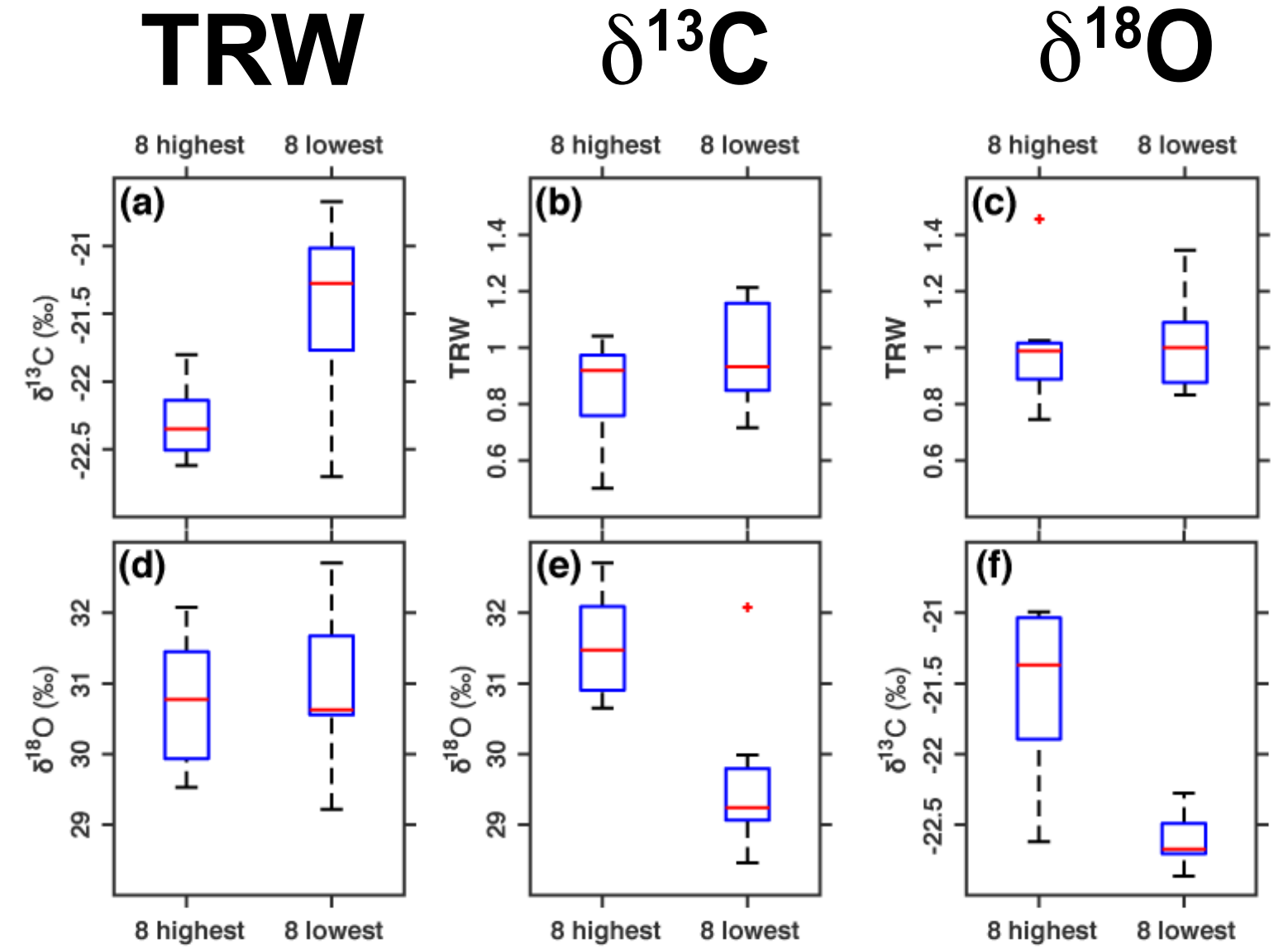

FIG. 4. Box-and-whisker plots for the values of the tree-ring records during the 8 years of extreme high/low values for each tree-ring records: (left) TRW, (middle) $\delta^{13} \mathrm{C}$ and (right) $\delta^{18} \mathrm{O}$. The red line represents the median, the blue boxes delimit the 25 th and 75 th percentile (i.e. interquartile range) and whiskers the minimum and maximum values. 
TRW

(a) Extreme TRW yrs
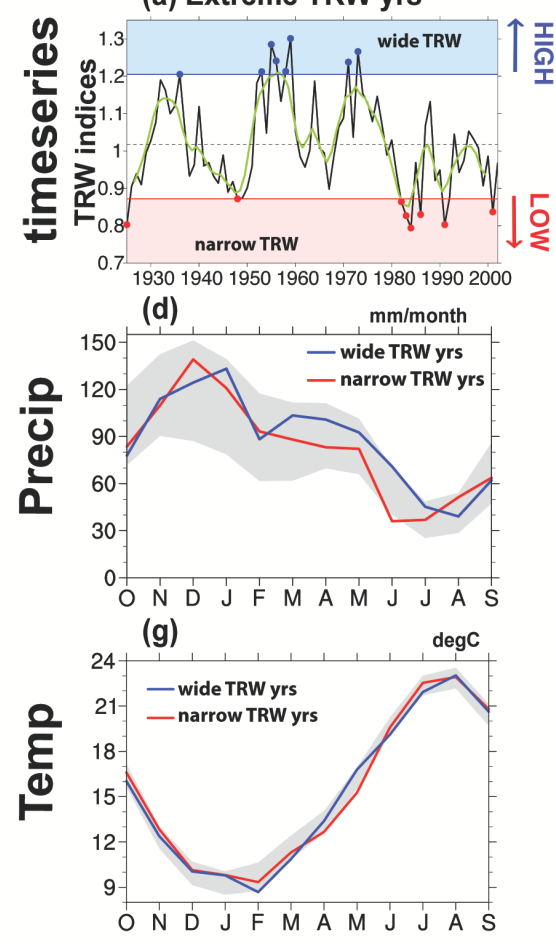

$\delta^{13} \mathrm{C}$

(b) Extreme $\delta^{13} \mathrm{C}$ yrs
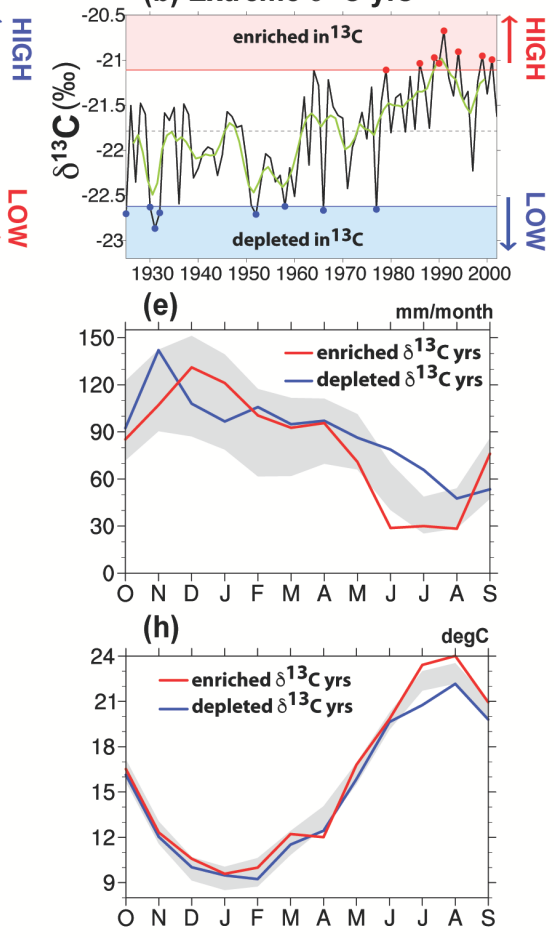

$\delta^{18} \mathrm{O}$

(c) Extreme $\delta^{18} 0$ yrs
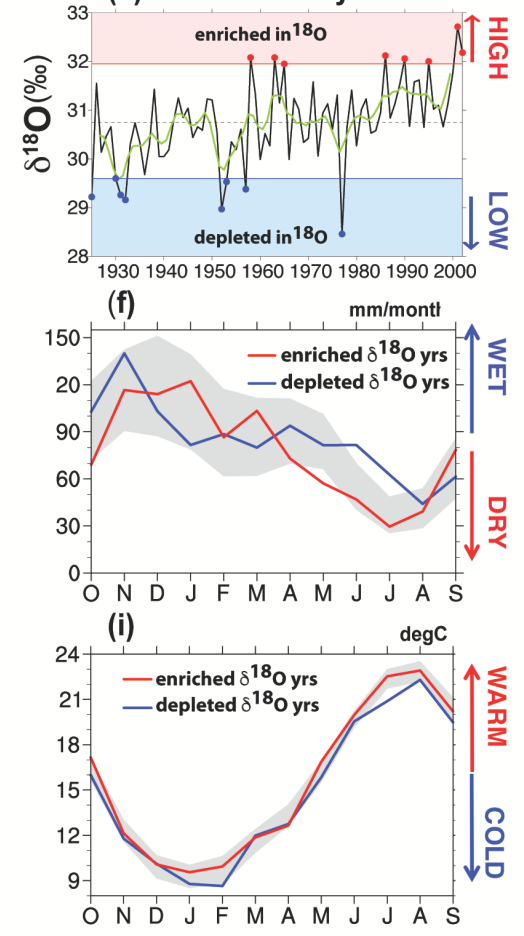

FIG. 5. Lillo tree-ring series and seasonal cycles for precipitation and temperature: (ac) Time-series of the Lillo tree-ring chronologies for the period 1925-2002 for (left) TRW, (middle) $\delta^{13} \mathrm{C}$, and (right) $\delta^{18} \mathrm{O}$. Annual values are shown in black, 5-year moving average in green, and years with extreme high and low values in the time-series highlighted with filled circles. (d-i) Average seasonal cycle (grey shading) and seasonal cycles during years with the extreme proxy values detected in (a-c) shown with coloured lines for (d-f) Lillo precipitation and (g-i) Lillo temperature. Where the coloured lines lie outside the grey shading, significant deviations from average conditions occur. 
$\begin{array}{ccc}\text { High TRW yrs } & \text { Low } \delta^{13} \mathrm{C} \text { yrs } & \text { Low } \delta^{18} \mathrm{O} \text { yrs } \\ \text { June (WET) } & \text { June-July (WET) } & \text { June-July (WET) }\end{array}$
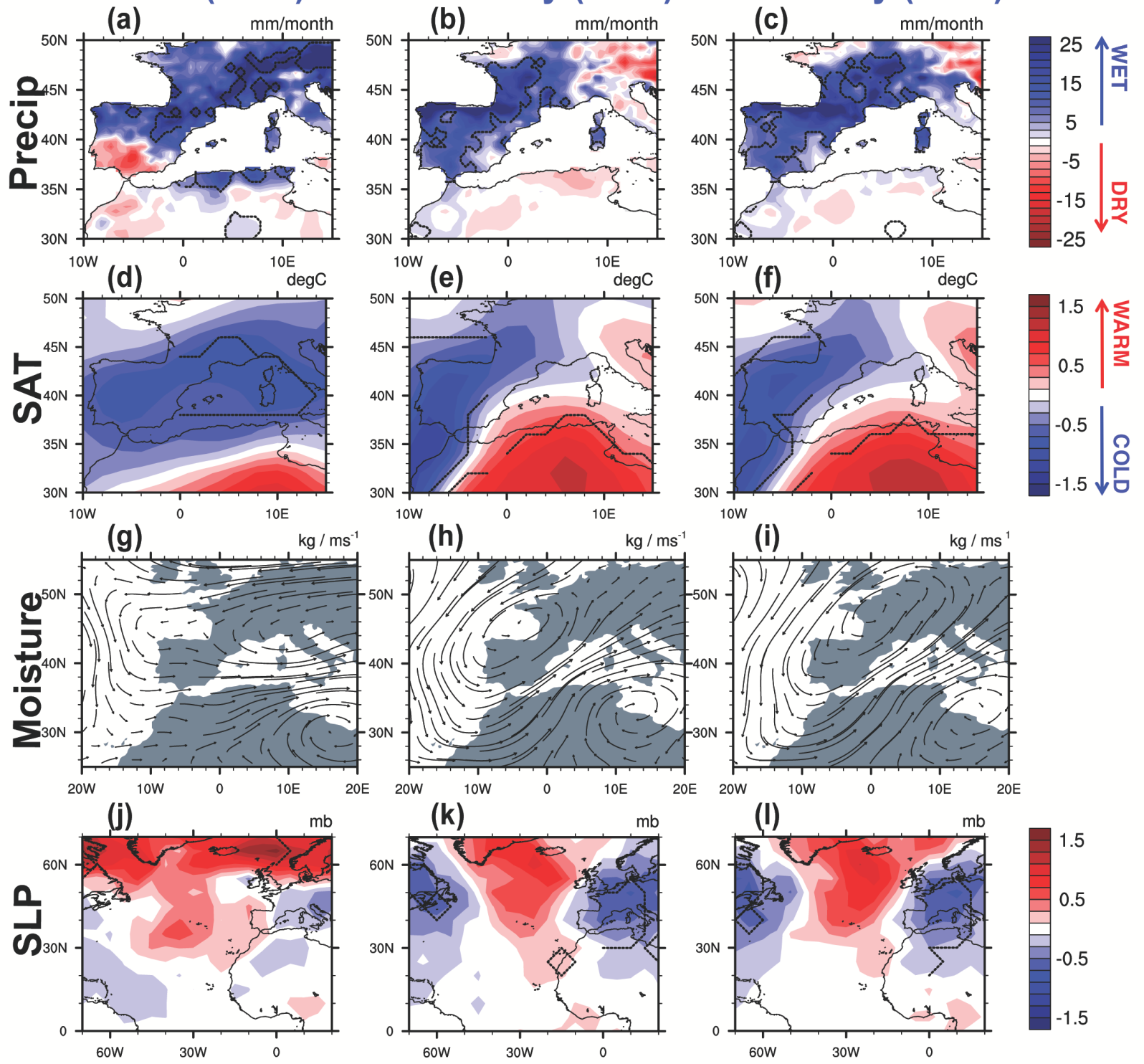
FIG. 6. Composites of wet summer conditions during years with extreme values in the tree-ring series in the studied instrumental period (1925-2002). Note that wet conditions correspond to wide (high) values in TRW and low values for both stable isotopic ratios $\left(\delta^{13} \mathrm{C}\right.$ and $\left.\delta^{18} \mathrm{O}\right)$. (a-l): Seasonal composite anomalies for years with extreme proxy values are shown for those months with significant deviations in the precipitation seasonal cycle (Fig. 5d-f) for (a-c) precipitation, (d-f) surface air temperature (SAT), (g-i) moisture transport integrated below 500hPa, and (j-1) Sea Level Pressure (SLP). Dashed contours and black arrows indicate anomalies significant at the $90 \%$ confidence level. 


\section{Low TRW yrs High $\delta^{13} C$ yrs High $\delta^{18} O$ yrs June (DRY)}
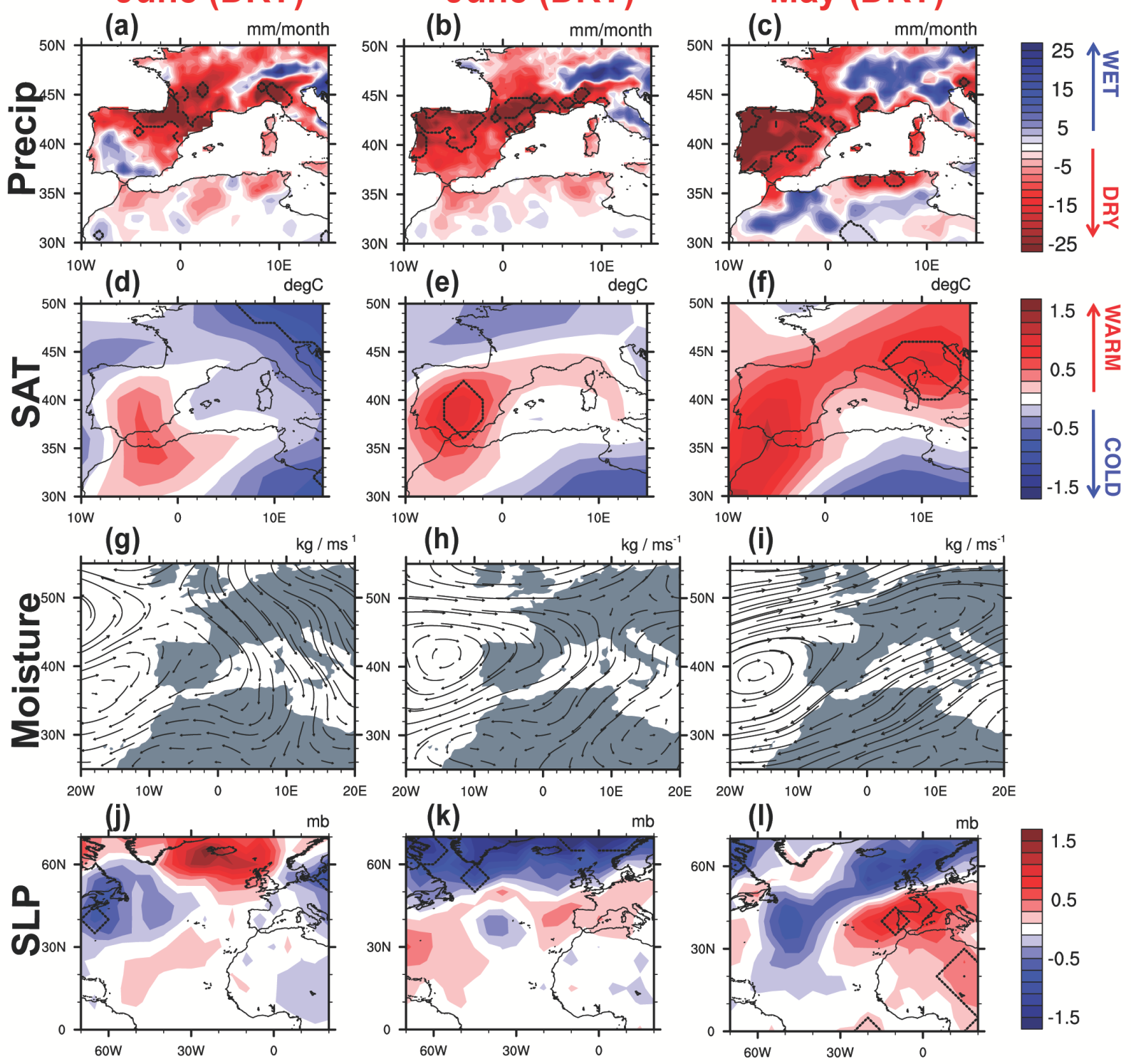
FIG. 7. Composites of dry summer conditions during years with extreme values in the tree-ring series for the studied instrumental period (1925-2002). Note that dry conditions correspond to narrow (low) values in TRW and high values for both stable isotopic ratios $\left(\delta^{13} \mathrm{C}\right.$ and $\left.\delta^{18} \mathrm{O}\right)$. (a-l): Seasonal composite anomalies for years with extreme proxy values are shown for those months with significant deviations in the precipitation seasonal cycle (Fig. 5d-f) for (a-c) precipitation, (d-f) surface air temperature (SAT), (g-i) moisture transport integrated below $500 \mathrm{hPa}$, and (j-1) Sea Level Pressure (SLP). Dashed contours and black arrows indicate anomalies significant at the $90 \%$ level. 


\section{High TRW yrs Low $\delta^{13} \mathrm{C}$ yrs Low $\delta^{18} \mathrm{O}$ yrs Jun (WET) Jun-Jul (WET)}
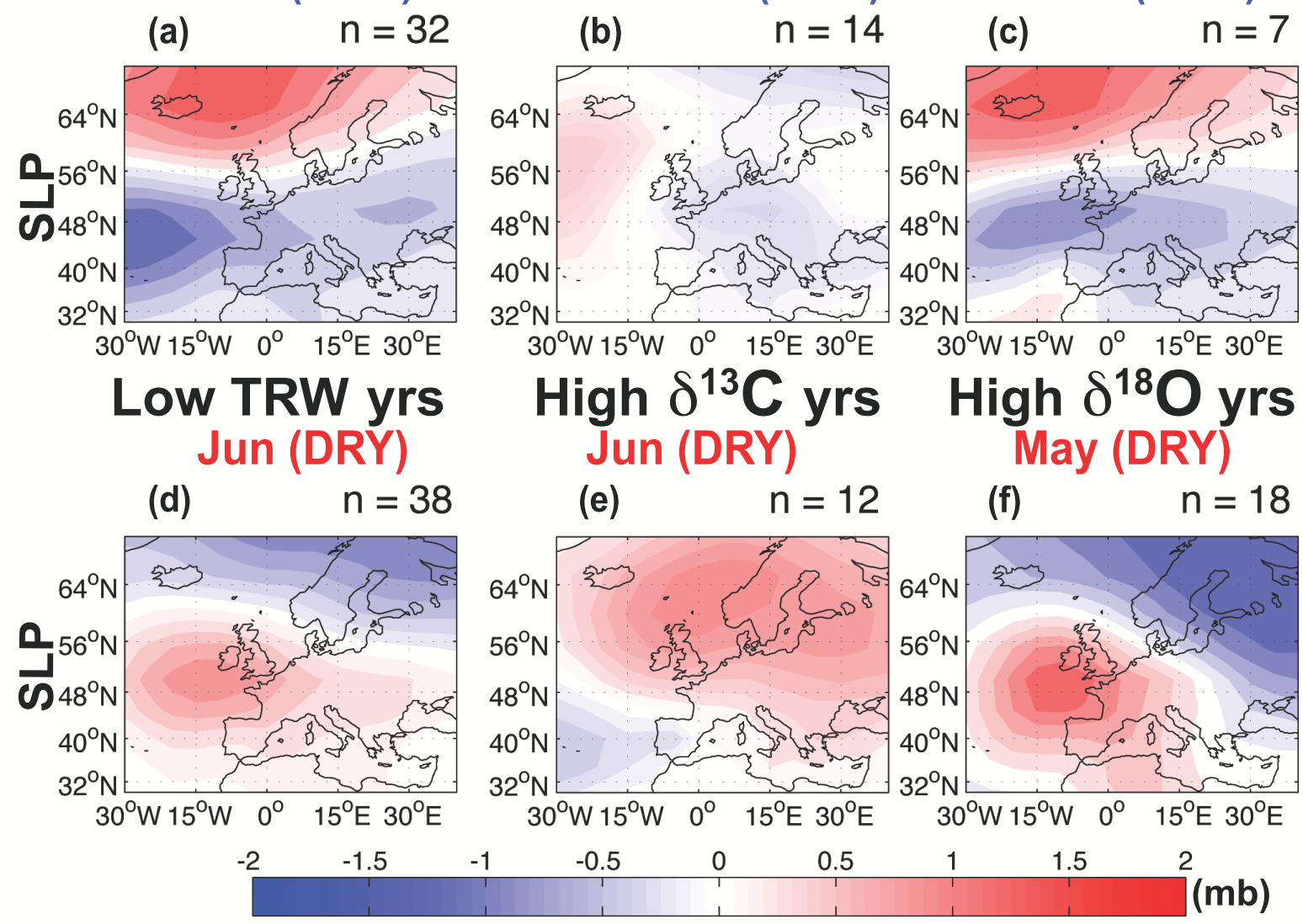

FIG. 8. Seasonal composite analyses of SLP $(\mathrm{mb})$ during years with extreme values in the tree-ring series for the pre-instrumental period (1665-1900). Note that wet conditions over the Lillo site correspond to wide (high) values in TRW (a) and low values for both stable isotopic ratios $\delta^{13} \mathrm{C}(\mathrm{b})$ and $\delta^{18} \mathrm{O}(\mathrm{c})$; dry conditions to narrow (low) values in TRW (d) and high values for both stable isotopic ratios $\delta^{13} \mathrm{C}(\mathrm{e})$ and $\delta^{18} \mathrm{O}$ (f). $\mathrm{n}$ indicates the number of extreme years used in each composite that was based on the criteria to select years above and below the threshold established in Fig. 3 . 


\section{High TRW yrs Low $\delta^{13} \mathrm{C}$ yrs Low $\delta^{18} \mathrm{O}$ yrs}
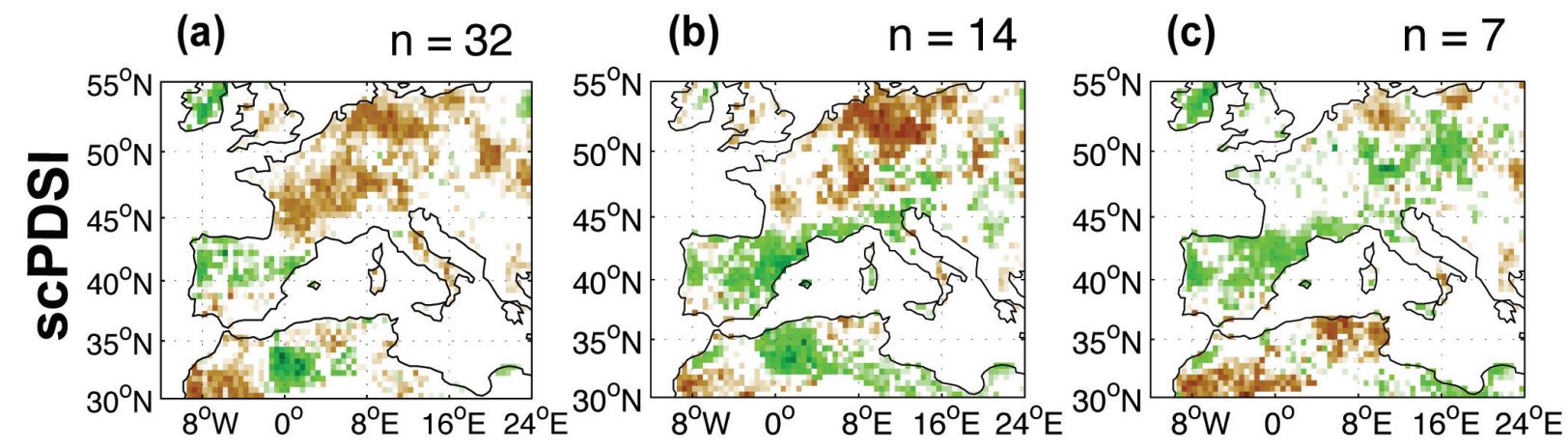

\section{Low TRW yrs}

High $\delta^{13} \mathrm{C}$ yrs

High $\delta^{18} \mathbf{O}$ yrs

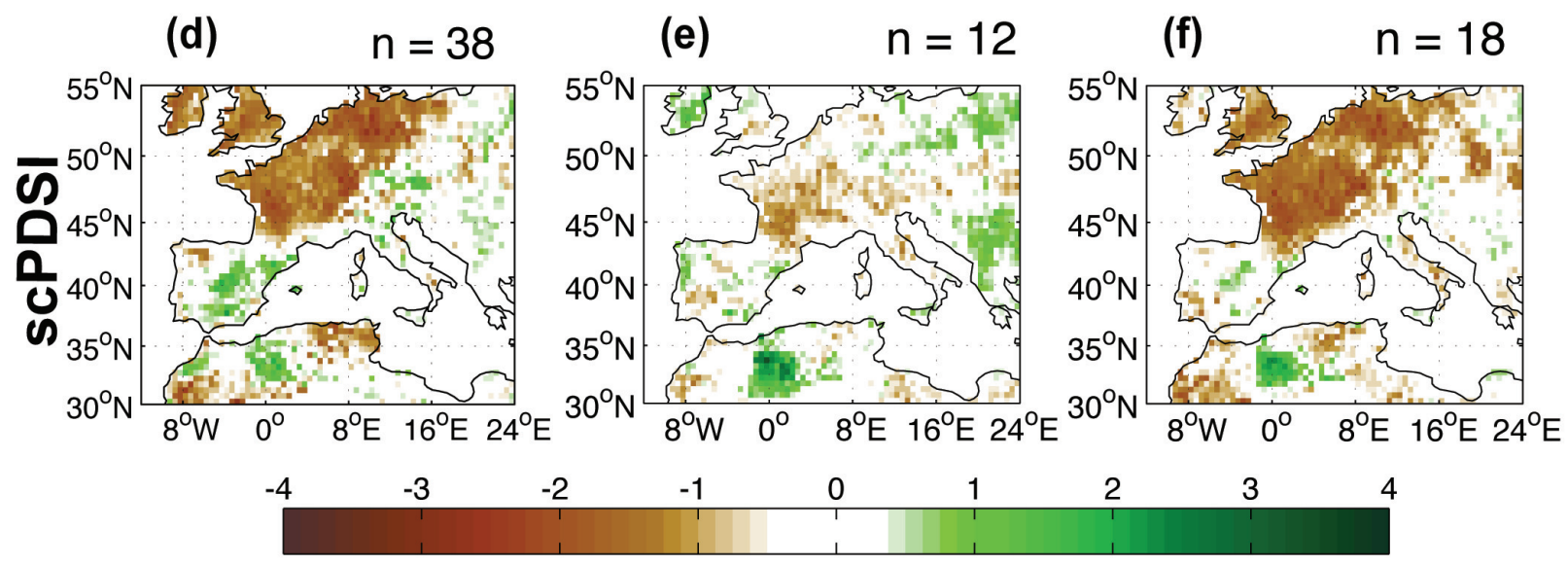

Fig. 9. As Fig. 8, but for the self-calibrating Palmer Drought Severity Index (scPDSI) from the Old World Drought Atlas. 




FIG. 10. As Fig. 8, but using the years detected by the 8 high / low proxy values for the instrumental period (1925-1999) for the SLP anomaly composites. $n$ indicates the number of extreme years used in each composite. Note that 7 years were used instead of 8 in some cases when the year 2001 needed to be excluded because it was not available in the SLP gridded product. 


\section{High TRW yrs Low $\delta^{13} \mathrm{C}$ yrs Low $\delta^{18} \mathrm{O}$ yrs}

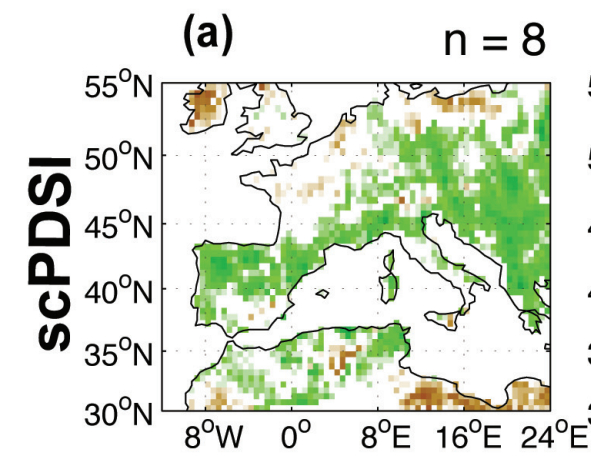

(b)

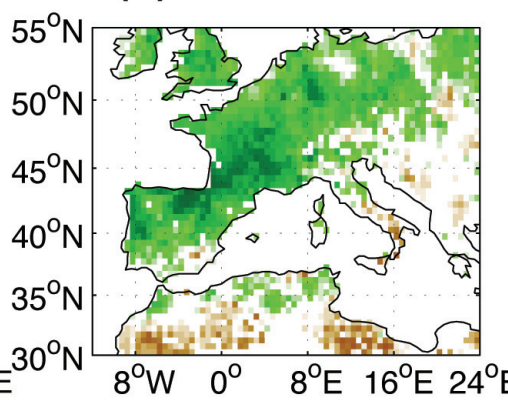

(e)

$\mathrm{n}=8$

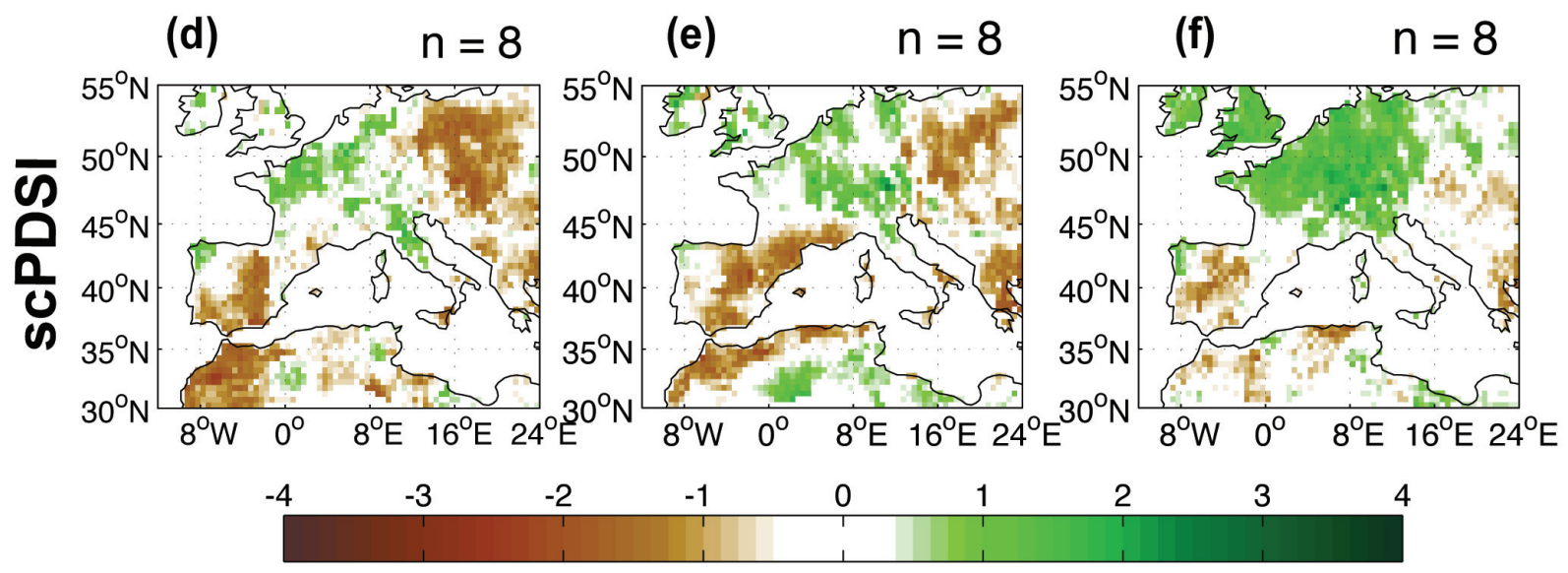

(c)

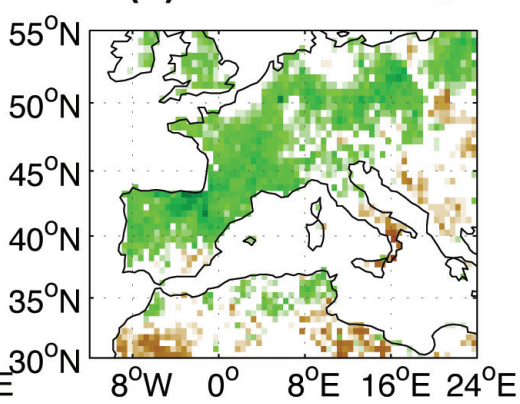

\section{Low TRW yrs High $\delta^{13} \mathrm{C}$ yrs High $\delta^{18} \mathrm{O}$ yrs}

Fig. 11. As Fig. 8, but using the years detected by the 8 high / low proxy values from the instrumental period (1925-2002) for the scPDSI anomaly composites. 

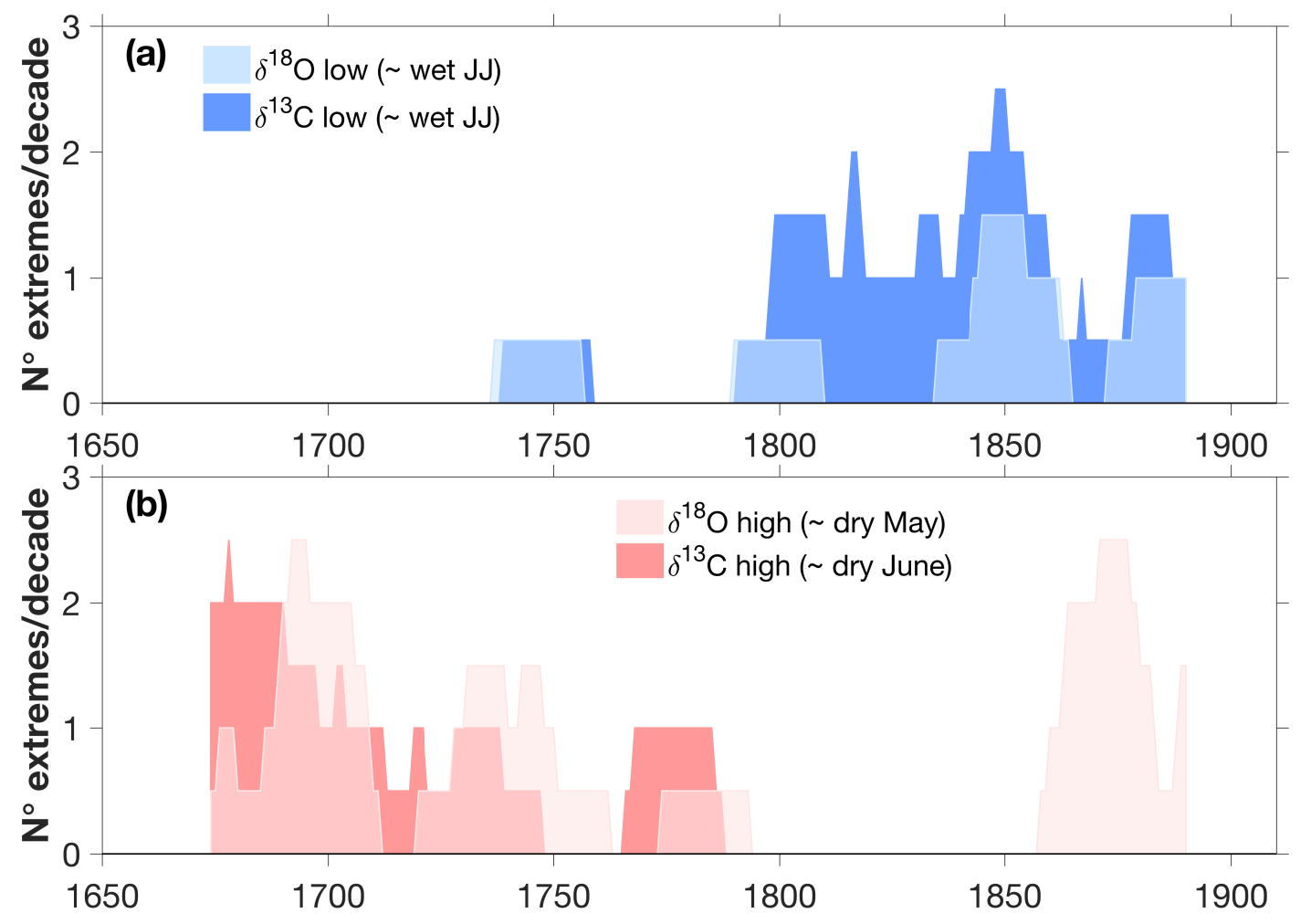

FIG. 12. Time-series of the number of extreme events in 20-yr sliding windows for the extreme values in both $\delta^{13} \mathrm{C}$ and $\delta^{18} \mathrm{O}$ records. Wet (dry) conditions are reflected by low (high) isotopic extreme values. 